\title{
Změny předpisů pro oceňování věcí nemovitých od 1. ledna 2021
}

\section{Amendments to the Valuation of Immovable Property from 1 January 2021}

\author{
Albert Bradáč $\mathfrak{a}^{*}$, Petr Polák ${ }^{\mathrm{b}}$ \\ ${ }^{a}$ Emeritní profesor oboru soudní inženýrství, Ústavu soudního inženýrství Vysokého učení technického v Brně \\ ${ }^{b}$ Ministerstvo financi $\check{C} R$
}

\begin{abstract}
Abstrakt
V článku jsou uvedeny a komentovány změny oceňování nemovitostí, které přinášejí novela zákona o oceňování majetku a novela prováděcí oceňovací vyhlášky k 1. lednu 2021.
\end{abstract}

Klíčová slova: nemovitost, nemovitá věc, stavba, právo stavby, pozemek, věcné břemeno, rychle rostoucí dřeviny, cena.

\section{ÚVODEM}

K 1. lednu 2021 nabývají účinnosti kromě nového zákona znaleckého a jeho prováděcích vyhláček také novela č. 237/2020 Sb. zákona č. 151/1997 Sb., o oceňování majetku, a vyhláška Ministerstva financí č. 488/2020 Sb., jež novelizuje vyhlášku č. 441/2013 Sb., k provedení zákona o oceňování majetku (oceňovací vyhlášku), ve znění vyhlášek č. 199/2014 Sb., č. 345/2015 Sb., č. 53/2016 Sb., č. 443/2016 Sb., č. 457/2017 Sb. a č. 188/2019 Sb. Účelem předkládaného př́spěvku je seznámit čtenáře podrobněji s těmito novelami, včetně důvodů, jež k jejich vydání vedly. $V$ př́spěvku jsou místy k novele oceňovací vyhlášky použity výňatky z důvodové zprávy MF ČR [5], u zákona pak ze sněmovního tisku Poslanecké sněmovny PČR č. 501 [2].

Příspěvek podává přehled o hlavních novelizacích zákona o oceňování majetku a oceňovací vyhlášky; některé formální změny, neměnící podstatu ocenění, jsou zde pominuty. Naopak vzhledem $\mathrm{k}$ účelu informace bylo nutno některá nová ustanovení citovat doslovně.

Zákon o oceňování majetku upravuje způsoby oceňování majetku a služeb pro účely stanovené jinými předpisy, mimo oblast cen sjednávaných mezi prodávajícím a kupujícím, kterou upravuje zákon č. 526/1990 Sb., o cenách, ve znění pozdějších předpisů. Podle zákona o oceňování majetku se určují ceny v ostatních případech, kdy se cena majetku stanovuje pro jiné účely než pro prodej.

V návaznosti na změny tržního a právního prostředí bylo potřebné několikrát zákon o oceňování majetku novelizovat;

\section{Abstract}

The article presents and comments on the changes in real estate valuation brought by the amendment to the Property Valuation Act and the amendment to the implementing valuation decree as of 1 January 2021.

Keywords: property, real thing, building, construction law, land, easements, fast growing woody plants, price.

zásadní novelizace proběhly v souvislosti s rekodifikací občanského zákoníku v roce 2013 (s účinností od 1. 1. 2014), se změnou zákonného opatření Senátu o dani z nabytí nemovitých věcí č. 340/2013 Sb. (nově je ovšem tato daň zrušena), se zákonným opatřením Senátu o změně daňových zákonů v souvislosti s rekodifikací soukromého práva a o změně některých zákonů č. 344/2013 Sb., se změnou zákona č. 228/2014 Sb. (autorský zákon) a se zákonem č. 225/2017 Sb., kterým se mění zákon č. 183/2006 Sb., o územním plánování a stavebním řádu (stavební zákon), ve znění pozdějších předpisů.

Novela oceňovací vyhlášky reaguje zejména na změny provedené v zákoně o oceňování majetku zákonem č. 237/2020 Sb. Hlavní úpravy v novele oceňovací vyhlášky se týkají oceňování některých nemovitých věcí; spočívají:

- v podrobnostech $\mathrm{k}$ určení obvyklé ceny a tržní hodnoty,

- ve stanovení součástí a podkladů pro zpracování cenové mapy stavebních pozemků, včetně postupu,

- v oceňování rychle rostoucích dřevin,

- v oceňování věcných břemen a závad na nemovité věci,

- v každoroční aktualizaci základních cen stavebních pozemků u vyjmenovaných obcí, jejich oblastí a některých krajů,

- obdobně v aktualizaci základních cen některých staveb pro ocenění porovnávacím způsobem a

- v pravidelné aktualizaci koeficientů změny cen staveb.

Ministerstvo financí při aktualizaci základních cen a při úpravách oceňovacích postupů pro určování zjištěné ceny nemovitých věcí 
jako zpracovatel vychází z prováděných analýz a statistického vyhodnocení údajů z prodejů nemovitých věcí za rok 2019, které ministerstvu dle ustanovení § 33 odstavec 3 zákona o oceňování majetku předávají finanční úřady. V novele oceňovací vyhlášky jsou rovněž řešeny a zohledněny konstruktivní připomínky, vznesené odbornou veřejností, pokud byly opodstatněné nebo přínosné pro objektivitu určovaných cen a bylo možno je aplikovat pro obecné použití. Respektuje přitom její znalost místních podmínek a používání právního předpisu v praxi

Níže jsou uvedeny hlavní změny podrobněji.

\section{OBVYKLÁ CENA A REÁLNÁ HODNOTA}

Zákon o oceňování majetku řeší především oceňování majetku pro stanovení základu daně, at' již některé z daní majetkových, prríjmových, daně z přidané hodnoty $(\mathrm{DPH})$ či poplatků. Pro správné vyměření daně je tedy nezbytné zajistit objektivní ocenění, a to oceňovacím předpisem. Zákon proto nastavuje obecná kritéria a zásady, týkající se oceňování. Slouží pro kontrolu nesprávného ocenění, tím se podílí i na omezení daňových úniků. Cena podle zákona o oceňování majetku slouží také jako srovnávací úroveň při nákupu věcí do vlastnictví státu, popřípadě při prodeji státního majetku k posouzení hospodárnosti transakce. Jedná se o zásadní věc rovněž pro banky, které se ve svých standardech odvolávají právě na zákon o oceňování majetku.

Obecně vychází oceňování majetku z obvyklé ceny, definované v ustanovení § 2 zákona o oceňování majetku. Obvyklou cenou se podle tohoto ustanovení oceňuje majetek a služby, pokud zákon nestanoví jiný způsob oceňování. Obvyklá cena se stále více uplatňuje i u nemovitých věcí, především v př́ípadech, kdy na ni jiný právní předpis odkazuje.

Novela zákona převzala původní definici ceny obvyklé, oddělila ji však do samostatného odstavce 2 pragrafu 2; doplněno bylo, že se vztahuje na majetek a služby a že se stanoví porovnáním ze sjednaných cen. Oceňovací vyhláška pak v novém § 1a stanoví podrobnější postup při jejím stanovení:

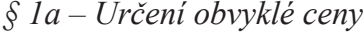

(1) Obvyklá cena se určuje porovnáním sjednaných cen stejných, popř́padě obdobných predmètů ocenění v obvyklém obchodním styku v tuzemsku ke dni ocenění. Do porovnání se nezahrnují ceny sjednané za vlivu mimoŕádných okolností trhu, osobnich pomérů prodávajicího a kupujicího ani vlivu zvláśtni obliby.

(2) Postup určeni obvyklé ceny zahrnuje

a) výběr údajů do souboru pro porovnáni s predmětem oceněni nejméně od 3 obdobnýchpredmětů na základě kritérii podle druhu předmětu oceněni a jehozvláštnosti ke dni ocenění,

b) srovnávaci analýzu údajů z vybraného souboru obdobných předmětů ocenění s údaji o oceňovaném předmětu ocenění,

c) určení základni jednotky pro porovnání a parametrů $s$ významným podílem na výśi ceny, určeni rozdíli parametrù mezi oceňovanými predmèty ocenéní a obdobnými předměty ocenění,

d) úpravu sjednaných cen v návaznosti na odlišnost obdobných predmétů ocenění od předmètů oceňovaných jejich korekcí, přičemž odchylka způsobená korekcí musí být řádně odůvodněna, e) výběr, odi̊vodnění a provedení analýzy s vyhodnocením souboru upravených cen včetně zdůvodněného prípadného vyloučeni odlehlých údaju a

f) určeni obvyklé ceny, která vycházi z vyhodnocení souboru upravených cen.

(3) Údaje použité pro určeniobvyklé ceny musí být kontrolovatelné a postup jejich zpracováni musí být z ocenění zrejmý a doložený.

(4) Nemožnost určení obvyklé ceny podle odstavců 1 a 2 je nutné doložit, zejména uvést postupy, které byly pro zjištěni realizovaných cen obdobných predmětů ocenění provedeny, a jejich výsledky.

Obvyklá cena předmětu ocenění se určí vyhodnocením vybrané množiny prvků realizovaných cen srovnatelných předmětů k datu ocenění. Množina prvků je vybírána $\mathrm{v}$ přiměřeném historickém časovém intervalu podle předem nastavených kritérií výběru. Soubor musí obsahovat podle povahy oceňovaného předmětu dostatečný počet údajů, tzn. minimálně tři údaje, a to po vyloučení odlehlých údajů (extrémů). Analýza údajů vybraného souboru se provádí z hlediska hodnototvorných aspektů, na základě jejího vyhodnocení se pak určí obvyklá cena.

Pokud nebyly srovnatelné předměty ani $\mathrm{v}$ přiměřeném období obchodovány, lze je vyjimečně ocenit postupem pro určení tržní hodnoty (viz dále) za předpokladu, že při jejím stanovení se vychází pouze ze všeobecně známých a doložitelných skutečností a faktů $\mathrm{k}$ datu ocenění.

Mimořádnými okolnostmi trhu se rovněž rozumí mimořádné podmínky trhu.

Ustanovení § 1a se rovněž týká obvyklé ceny nájemného (též „obvyklé nájemné“).

Znalec musí odůvodnit výběr údajů, stejně jako vhodnou volbu použitých analytických metod i provedení propočtu s korekcí upravených cen; hodnocení musí vycházet z vypočtených hodnot a musí být doloženo. Pouze slovní nepodložené hodnocení a konstatování, že vychází z vlastních zkušeností, je nedostačující.

Cena obvyklá se podle zákona o oceňování majetku určuje výhradně porovnáním kupních (sjednaných) cen srovnatelných věcí. $\mathrm{V}$ některých př́padech však není jednoduché kupní cenu srovnatelných věcí zjistit, bud' z důvodu její jedinečnosti, nebo proto, že se $\mathrm{s}$ ní $\mathrm{v}$ dané lokalitě a $\mathrm{v}$ přiměřeném časovém úseku neobchodovalo. $Z$ těchto důvodů považovali autoři novely zákona $\mathrm{s}$ ohledem na současný stav trhu za potřebné rozšírit možnosti ocenění věcí o určení tržní hodnoty. Lze předpokládat, že zavedením tržní hodnoty do zákona o oceňování majetku bude $\mathrm{v}$ príípadech, kdy nelze z výše uvedených důvodů určit obvyklou cenu, umožněno odkázat $\mathrm{v}$ jiných právních předpisech na tento již delší dobu požadovaný náhradní způsob ocenění. Definice tržní hodnoty je uvedena v novém ustanovení $§ 2$ odst. 3 až 5 zákona:

(3) V odi̊vodněných připadech, kdy nelze obvyklou cenu určit, oceňuje se majetek a služba tržni hodnotou, pokud zvláštni právni předpis nestanoví jinak. Přitom se zvažuji všechny okolnosti, které mají na tržni hodnotu vliv. Dưvody pro neurčeni obvyklé ceny museji být v oceněni uvedeny.

(4) Tržní hodnotou se pro účely tohoto zákona rozumí odhadovaná částka, za kterou by měly být majetek nebo služba směněny ke dni oceněni mezi ochotným kupujicím a ochotným prodávajicim, a to $v$ obchodním styku uskutečněném v souladu s principem tržního odstupu, po náležitém marketingu, kdy každá ze stran jednala informovaně, uvážlivě a nikoliv tísni. Principem tržního odstupu se pro účely tohoto zákona rozumí, že účastníci směny jsou osobami, 
které mezi sebou nemají žádný zvláštní vzájemný vztah a jednaji vzájemně nezávisle.

V odst. 5 pak je uvedeno, že určení obvyklé ceny a tržní hodnoty a postup při tomto určení musejí být z ocenění zřejmé, jejich použití, včetně použitých údajů, musí být odůvodněno a odpovídat druhu předmětu ocenění, účelu ocenění a dostupnosti objektivních dat, využitelných pro ocenění. Podrobnosti k určení tržní hodnoty stanoví vyhláška v novém ustanovení § $1 \mathrm{~b}$ :

(1) Tržni hodnotou predmětu oceněni je odhadovaná částka, která se určuje zpravidla na základě výběru z více způsobu oceňování, a to zejména způsobu porovnávacího, výnosového nebo nákladového. Při určení tržní hodnoty predmětu ocenění se zohledňuji tržní rizika a předpokládaný vývoj na dílčím či mistním trhu, na kterém by byl obchodován.

(2) Při určeni tržni hodnoty předmětu ocenění, s výjimkou služeb, se přihliži k možnosti jeho nejvyššiho a nejlepšiho využití, které je ke dni oceněni možné, fyzicky dosažitelné, právně připustné a ekonomicky proveditelné. ${ }^{\text {I) }}$

(3) Údaje použité pro určení tržní hodnoty musí být kontrolovatelné a postup jejich zpracování, včetně použití jednotlivých zpưsobì oceňování, musí být z ocenění ž̌ejmý a doložený.

Tržní hodnota se stanovuje na základě vyhodnocení určených cen (hodnot) a výběrem $\mathrm{z}$ více způsobů oceňování. Při ocenění (s výjimkou služeb) se zvažuje nejlepší možné využití předmětu, kterým se rozumí dosažení nejvyšší možné hodnoty, které lze jejím využitím dosáhnout, a které je reálné, právně přípustné a finančně proveditelné. Tržní hodnota se stanovuje pro běžného kupujicího. Tržní hodnotou předmětu ocenění není předem dohodnutá částka nebo skutečná prodejní cena. Zvolený způsob ocenění, ze všech možných způsobů ocenění, je potřeba řádně odůvodnit.

Ustanovení § 1 b se rovněž týká tržní hodnoty nájemného, též „tržní nájemné“.

Nový § 1c pak stanoví, že spolu s určením obvyklé ceny nemovité věci nebo její tržní hodnoty se určí i cena zjištěná. Př́ípadné rozdíly v ocenění je tř̌eba náležitě odůvodnit. Stanovení zjištěné ceny slouží jako kontrolní cenová hladina pro srovnání úrovně ocenění. Případné rozdíly je třeba náležitě odůvodnit, rovněž důvody nestanovení obvyklé ceny musí být zpracovatelem ocenění uvedeny; výjimku tvoří určení ceny obvyklé a tržní hodnoty $\mathrm{v}$ př́ípadech nemovitého zajištění pro subjekty podléhající regulaci spojené s výkonem činnosti bank, spořitelních a úvěrových družstev.

\section{Cena zjištěná - pozemky}

Ocenění stavebních pozemků vychází ze sjednaných cen (cenové mapy stavebních pozemků, porovnávací způsob), u zemědělských pozemků z předpokládaných výnosů, u lesních pozemků z výnosového a porovnávacího způsobu podle plošně převládajících souborů lesních typů.

Definice stavebního pozemku se prakticky nezměnila. Jako dřive je prioritním ocenění podle cenové mapy stavebních pozemků (CMSP); v $§ 2$ odst. 1 a 2 oceňovací vyhlášky je nově podrobně definován způsob jejího zpracování. V $\S 5$ a 6 pak je stanoveno, že pozemek, který není podle $\S 9$ odst. 2 zákona o oceňování majetku stavebním pozemkem, nelze podle cenové mapy stavebních pozemků ocenit. Takový pozemek se ocení podle př́slušného

1) Pozn. autorů: Tzv. metoda nejvyššího a nejlepšího využití - High And Best Use (HABU) ustanovení oceňovací vyhlášky ( 33 až 5). Podle uřesnění v $§ 10$ odst. 1 novelizovaného zákona není-li stavební pozemek oceněn v cenové mapě nebo nelze-li stavební pozemek ocenit cenou z cenové mapy, ocení se násobkem výměry pozemku a základní ceny za $\mathrm{m}^{2}$, upravené o vliv polohy a o další vlivy, působící zejména na využitelnost pozemků pro stavbu, popřípadě ceny určené jiným způsobem oceňování podle $§ 2$, které stanoví vyhláška.

$\mathrm{V}$ př́loze č. 2 oceňovací vyhlášky v tabulce č. 1 jsou aktualizovány základní ceny za $\mathbf{m}^{2}$ stavebního pozemku ve vyjmenovaných obcích, jejich oblastech a okresech na základě sjednávaných cen a analýz údajů, které MF předávají územní pracoviště Finančních úřadů v návaznosti na ustanovení § 33 odst, 3 zákona o oceňování majetku; změny oproti předchozí verzi oceňovací vyhlášky viz mj. obr. č. 1 až 3 a tab. č. 1 .

$\mathrm{V}$ př́loze č. 3 oceňovací vyhlášky $\mathrm{v}$ tabulce č. 1, ve znaku 8 - poloha obce, dochází u popisu kvalitativního pásma II., III. a V. k upřesnění textu, tj. za text ,v tabulce č. 1 “ se vkládá text ,přílohy č. 2“.

V prŕloze č. 20 (Koeficient polohový $K_{5}$ ) pak věta za tabulkou č. 1 zní:

Pro liniové inženýrské stavby (popřipadè jeji převažujici část) nacházejicí se v zastavěném území obce se použije u položek č. 1 a 2 maximálni hodnota koeficientu polohy $K_{5}$ zvýšená o $10 \%$, a u položek 3, 4 a 5 se hodnota koeficientu zvýśi o $15 \%$.

Pozemky zemědělské ( $§ 11 \mathrm{ZOM}, \S 6 \mathrm{OV})$ - beze změn, př́ilohy rovněž beze změn.

Lesní pozemek a nelesní pozemek s lesním porostem $(\S 12$ $\mathrm{ZOM}, \S 7 \mathrm{OV}$ ) - beze změn. př́lohy rovněž beze změn.

Pozemek vodní plochy, jiný pozemek ( $\$ 13$ ZOM, § 8 a 9 OV) - beze změn, přílohy rovněž beze změn.

\section{Cena zjištěná - stavby včetně jednotek (bytů a nebytových prostorů) \\ Nákladový způsob ocenění staveb}

U nemovitých věcí, které jsou stavbami, se při oceňování uplatňuje nákladový způsob, kombinace nákladového a výnosového způsobu a způsob porovnávací.

U nákladového způsobu ocenění ( $\S 10$ až 30 OV) došlo prakticky jen $\mathrm{k}$ aktualizaci koeficientů změny cen staveb $\mathrm{v}$ př́loze č. 41. Průběh $K_{\mathrm{i}}$ od roku 1994 je zřejmý z obr. 4. U průměru se zde jedná o prostý aritmetický průměr hodnot z př́lohy č. 41 .

\section{Porovnávací způsob ocenění staveb}

Porovnávací způsob ocenění ( $\S 34-38$ ) - text nezměněn, nové jsou hodnoty ZC v př́lohách č. 24 až 27 . V Karlovarském kraji v současné době žádná obec „,nad 50000 obyvatel“ nedosahuje, proto není $\mathrm{v}$ této kolonce $\mathrm{v}$ novele vyhlášky uvedena základní cena.

Na grafech v obrázcích č. 5 až 9 je uveden vývoj ZC od roku 2009 (zavedení ocenění porovnávacím způsobem) do roku 2021 (dříve tzv. IPC - indexovaná průměrná cena; s přechodem na ZC a změnou metodiky zrejmě souvisejí skoky od roku 2013). U průměru se zde jedná o prostý aritmetický průměr hodnot z př́slušných příloh.

\section{Oceňování kombinací nákladového a výnosového způsobu}

Oceňování kombinací nákladového a výnosového způsobu ( $\$ 31$ až $33 \mathrm{OV}$ ) - zde při poslední novelizaci nedošlo k žádným změnám v textu; v př́loze č. 22 (míry kapitalizace) byl v tabulce doplněn text řádku 17 a vložen nový rádek 18: 


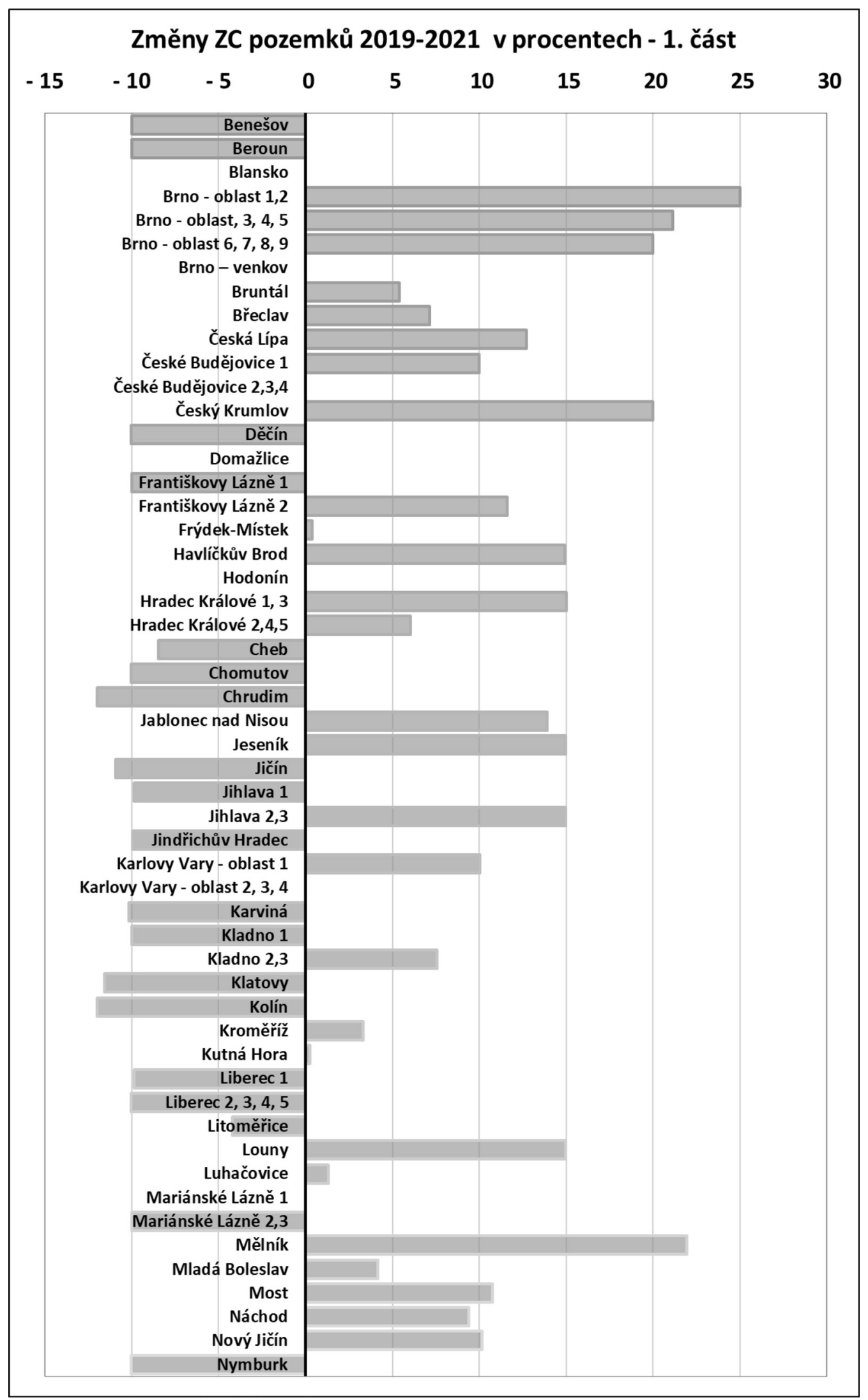

Obr. 1 Změny základnich cen pozemki 2019/2021 u vyjmenovaných obcí resp. jejich částí v tabulce č. 1 v př́loze č. 2 oceňovací vyhláškyčást 1 (Zpracování: vlastní).

Fig. 1 Changes in the basic price of the land, 2019/2021 at the listed municipalities or their parts in table 1 in the annex no. 2 to the valuation of the decree - part 1 (Handle: custom). 


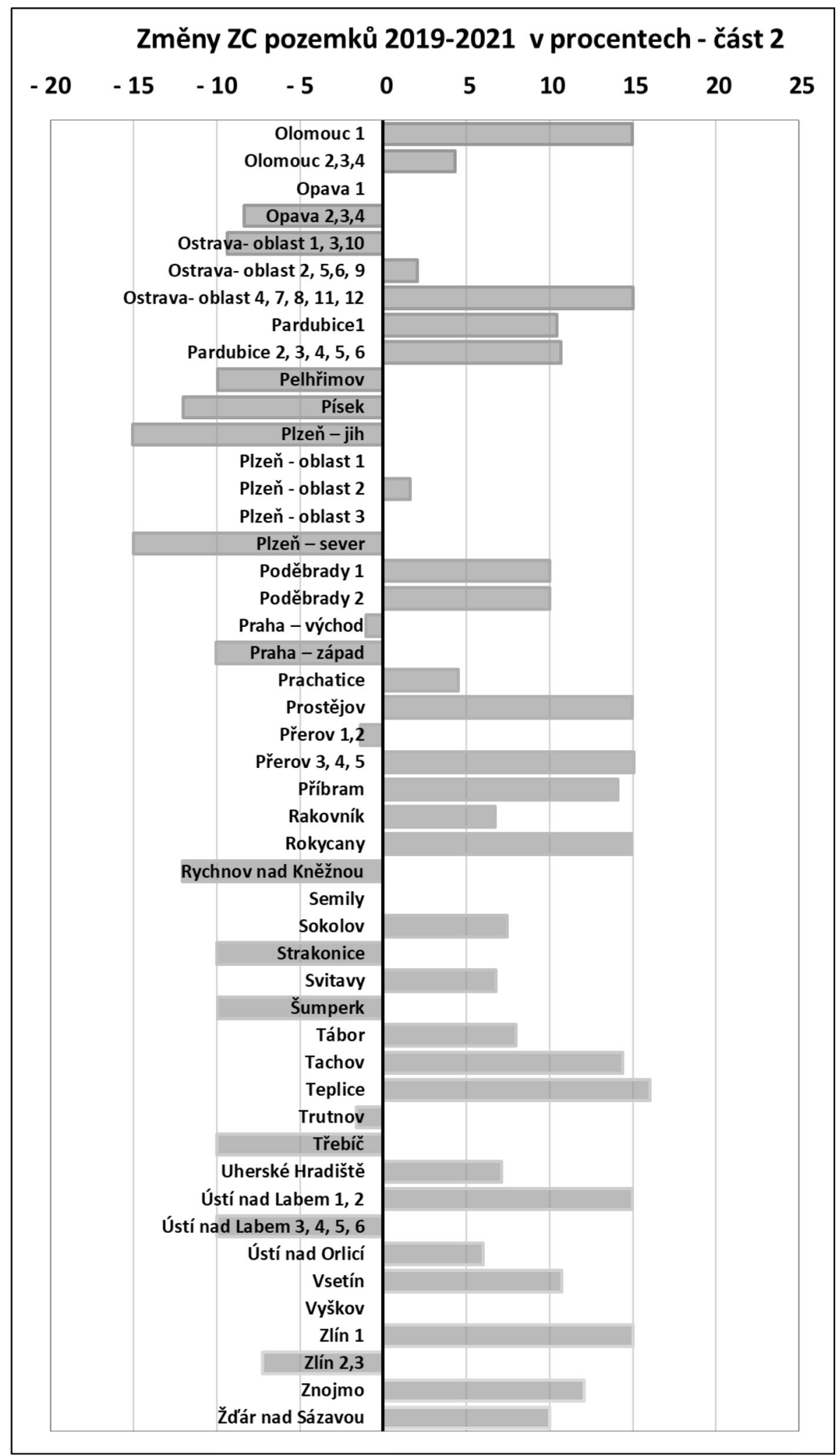

Obr. 2 Změny základnich cen pozemki 2019/2021 u vyjmenovaných obcí resp. jejich částí v tabulce č. 1 v př́loze č. 2 oceňovací vyhláškyčást 2 (Zpracování: vlastní).

Fig. 2 Changes in the basic price of the land, 2019/2021 at the listed municipalities or their parts in table 1 in the annex no. 2 to the valuation of the decree - part 2 (Handle: custom). 
Tab. 1 Změny základních cen stavebnich pozemků 2019/2021 - Praha; oblasti podle přilohy č. 2 oceňovací vyhlášky (Zpracování: vlastní). Tab. 1 Changes in basic prices of building plots, 2019/2021-Prague; areas according to Annex 2 of the valuation decree (Handle: custom).

\begin{tabular}{|c|c|c|c|c|}
\hline Praha oblast & Katastrální území & $\begin{array}{l}\text { ZC } 2019 \\
\text { Ǩ̌ } / \mathbf{m}^{2}\end{array}$ & $\begin{array}{c}\mathrm{ZC} 2021 \\
\mathrm{Kč} / \mathbf{m}^{2}\end{array}$ & $\begin{array}{c}\text { Změna ZC } \\
\%\end{array}$ \\
\hline 1 & Hradčany, Josefov, Malá Strana, Nové Město, Staré Město & 65075 & 78090 & 20,00 \\
\hline 2 & Vinohrady, Vyšehrad & 17002 & 18330 & 7,81 \\
\hline 3 & Holešovice, Karlín, Žižkov & 17002 & 18330 & 7,81 \\
\hline 4 & Braník, Hodkovičky, Krč, Lhotka, Michle & 7999 & 8494 & 6,19 \\
\hline 5 & Hlubočepy, Jinonice, Košíre, Motol, Radlice & 7999 & 8494 & 6,19 \\
\hline 6 & Břevnov, Bubeneč, Dejvice, Troja, Střešovice, Veleslavín & 17002 & 18330 & 7,81 \\
\hline 7 & Ď́alice, Kbely, Letňany & 6126 & 7351 & 20,00 \\
\hline 8 & Bohnice, Čimice, Dolní Chabry, Lysolaje, Sedlec, Suchdol & 5134 & 5272 & 2,69 \\
\hline 9 & Libeň, Hloubětín, Kobylisy, Prosek, Stř̌́žkov, Vysočany & 7999 & 8494 & 6,19 \\
\hline 10 & Hrdlořezy, Malešice, Strašnice, Záběhlice & 7999 & 8494 & 6,19 \\
\hline 11 & $\begin{array}{l}\text { Dolní Měcholupy, Háje, Horní Měcholupy, Hostivař, Chodov, Petrovice, } \\
\text { Štěrboholy }\end{array}$ & 6126 & 7351 & 20,00 \\
\hline 12 & $\begin{array}{l}\text { Benice, Kamýk, Komořany, Kunratice, Křeslice, Libuš, Modřany, Pitkovice, } \\
\text { Šeberov, Újezd u Průhonic }\end{array}$ & 7999 & 8494 & 6,19 \\
\hline 13 & Cholupice, Královice, Lipany, Nedvězí, Písnice, Točná & 5134 & 5272 & 2,69 \\
\hline 14 & $\begin{array}{l}\text { Běchovice, Dolní Počernice, Dubeč, Hájek u Uhříněvsi, Koloděje, Kolovraty, } \\
\text { Uhříněves }\end{array}$ & 5134 & 5272 & 2,69 \\
\hline 15 & Březiněves, Čakovice, Miškovice, Satalice, Třeboradice, Vinoř, & 5134 & 5272 & 2,69 \\
\hline 16 & Radotín, Řeporyje, Zbraslav & 5134 & 5272 & 2,69 \\
\hline 17 & Lahovice, Lipence, Lochkov, Přední Kopanina, Sobín, Zadní Kopanina & 5134 & 5272 & 2,69 \\
\hline 18 & $\begin{array}{l}\text { Holyně, Malá Chuchle, Řepy, Slivenec, Stodůlky, Třebonice, Velká Chuchle, } \\
\text { Zličín }\end{array}$ & 7999 & 8494 & 6,19 \\
\hline 19 & Černý Most, Horní Počernice, Hostavice, Klánovice, Kyje, Újezd n. Lesy & 5134 & 5272 & 2,69 \\
\hline 20 & Liboc, Nebušice, Ruzyně, Vokovice, & 6126 & 7351 & 20,00 \\
\hline \multirow[t]{2}{*}{21} & Nusle, Podolí, Smíchov, Vršovice & 17002 & 18330 & 7,81 \\
\hline & Průměr - př́růstek \% & & & 9,93 \\
\hline
\end{tabular}

\begin{tabular}{lll}
\hline $17-$ & Majetková práva, není-li dále uvedeno jinak & 10 \\
\hline $18-\begin{array}{l}\text { Pozemky nezastavěné, které nejsou v jednotném } \\
\text { funkčním celku, zatí̌ené věcným břemenem }\end{array}$ & 10 \\
\hline
\end{tabular}

Za tabulkou pak byl text doplněn o nová ustanovení, týkající se ocenění věcných břemen pro technickou infrastrukturu:

Pro ocenění věcných břemen se použije míra kapitalizace podle druhu nemovité věci, kterou věcné břemeno zatěžuje, kromè věcných bremen pro technickou infrastrukturu, u nichž čini $10 \%$.

$V$ prípadě zatížení stavby věcným břemenem se použije míra kapitalizace pro tuto stavbu. Pro oceněni závady na nemovité věci se použije míra kapitalizace podle druhu zatižené nemovité věci.

U zastavěného pozemku nebo pozemku v jednotném funkčním celku zatíženého věcným břemenem se použije míra kapitalizace podle druhu hlavni stavby. Je-li na pozemku více hlavních staveb, které nejsou společně využivané, postupuje se podle § $48 a$ odst. 1 pism. c).

Míru kapitalizace lze v odůvodněných prípadech zvýšit až o $0,5 \%$.

\section{Věcná práva $\mathbf{k}$ nemovitým věcem Oceňování práva stavby}

Zde je zcela nový § 16a zákona o oceňování majetku: $\S 16 a-$ Oceňováni práva stavby

(1) Právo stavby se oceňuje výnosovým způsobem na základě ročního užitku při zohledněni doby dalšiho uživání práva, která uplyne v období od roku ocenèní do roku zániku práva.

(2) Pro ocenéní práva stavby s nezřizenou stavbou, která právu stavby vyhovuje, se zjistí ročni užitek z pozemku zatiženého tímto právem.

(3) Pro ocenéni práva stavby se zrízenou stavbou, která právu stavby vyhovuje, se roční užitek urči ze zjištěné ceny zatiženého pozemku a zjišténé ceny stavby, která právu stavby vyhovuje, a z náhrady při zániku práva stavby.

(4) Způsob výpočtu ceny práva stavby při zohlednění počtu let dalšiho trváni práva stavby, určeni ročního užitku a výše náhrady při zániku práva stavby stanoví vyhláška.

(5) Ocenění podle odstavců 2 a 3 se nepoužije, lze-li cenu práva stavby zjistit z rozhodnuti príslušného orgánu.

V oceňovací vyhlášce navazující § 39 zůstává beze změny. 


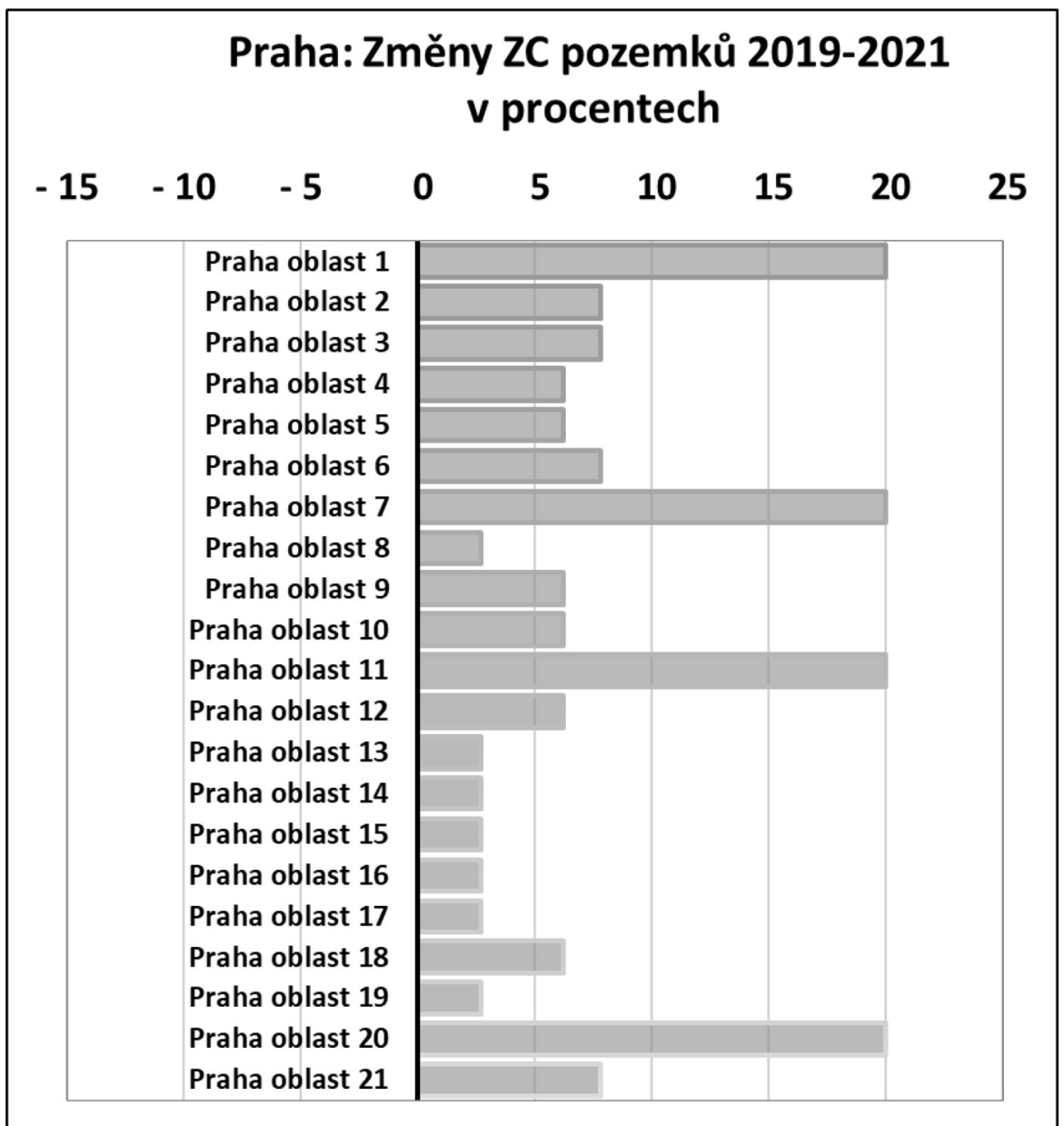

Obr. 3 Změny základnich cen stavebních pozemki̊ 2019/2021 - Praha (Zpracování: vlastní).

Fig. 3 Changes in basic prices of building plots, 2019/2021 - Prague (Handle: custom).

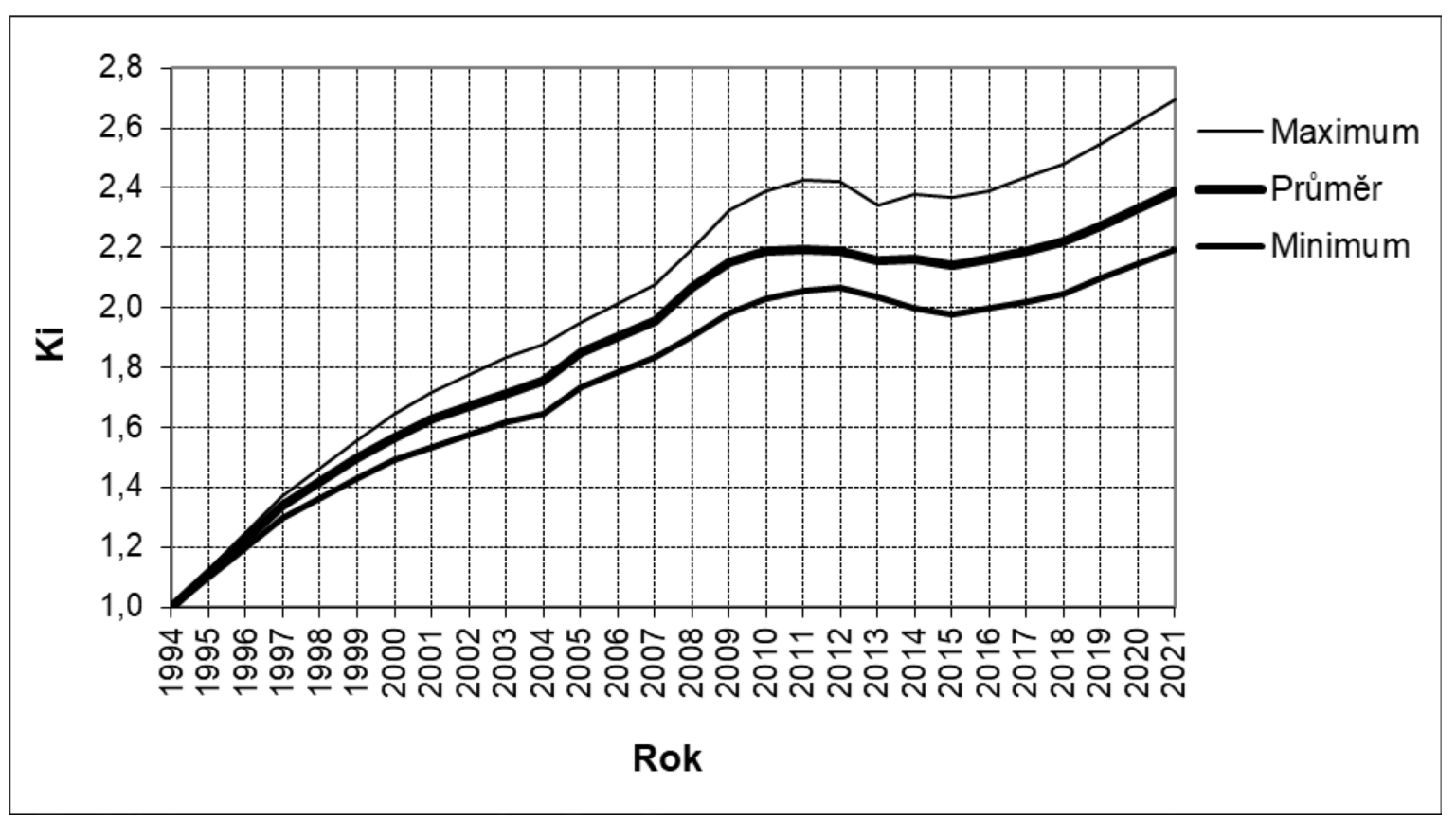

Obr. 4 Vývoj koeficientu změny cen staveb Ki v letech 1994-2019.

Fig. 4 Evolution of factor changes in prices of constructions Ki in the years 1994-2019. 


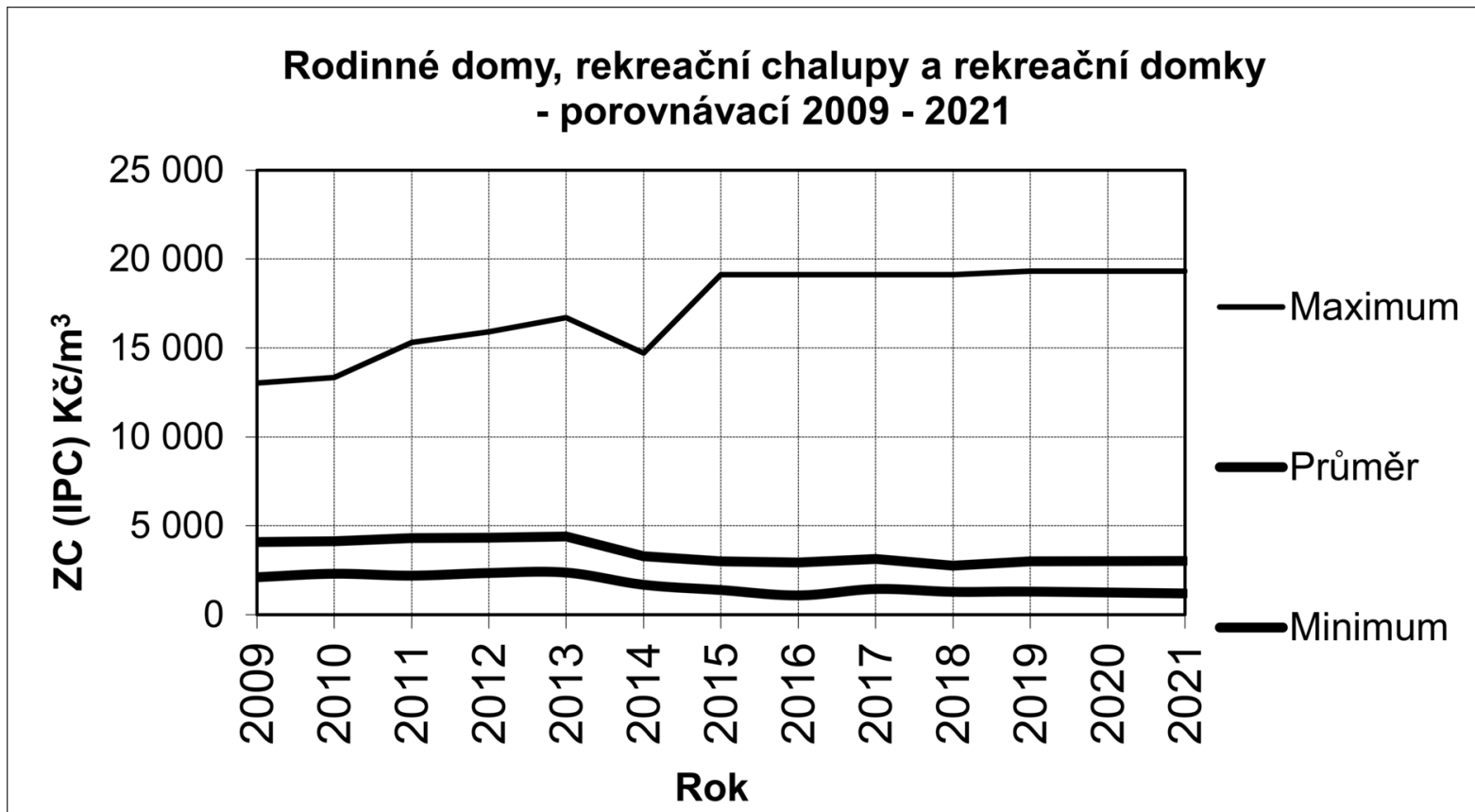

Obr. 5 Vývoj základních cen ZC u porovnávací metody v letech 2009-2018; rodinné domy, rekreační chalupy a rekreační domky. Fig. 5 Evolution of basic prices ZC with comparative methods in the years 2009-2018; family houses, vacation cottages and recreational houses.

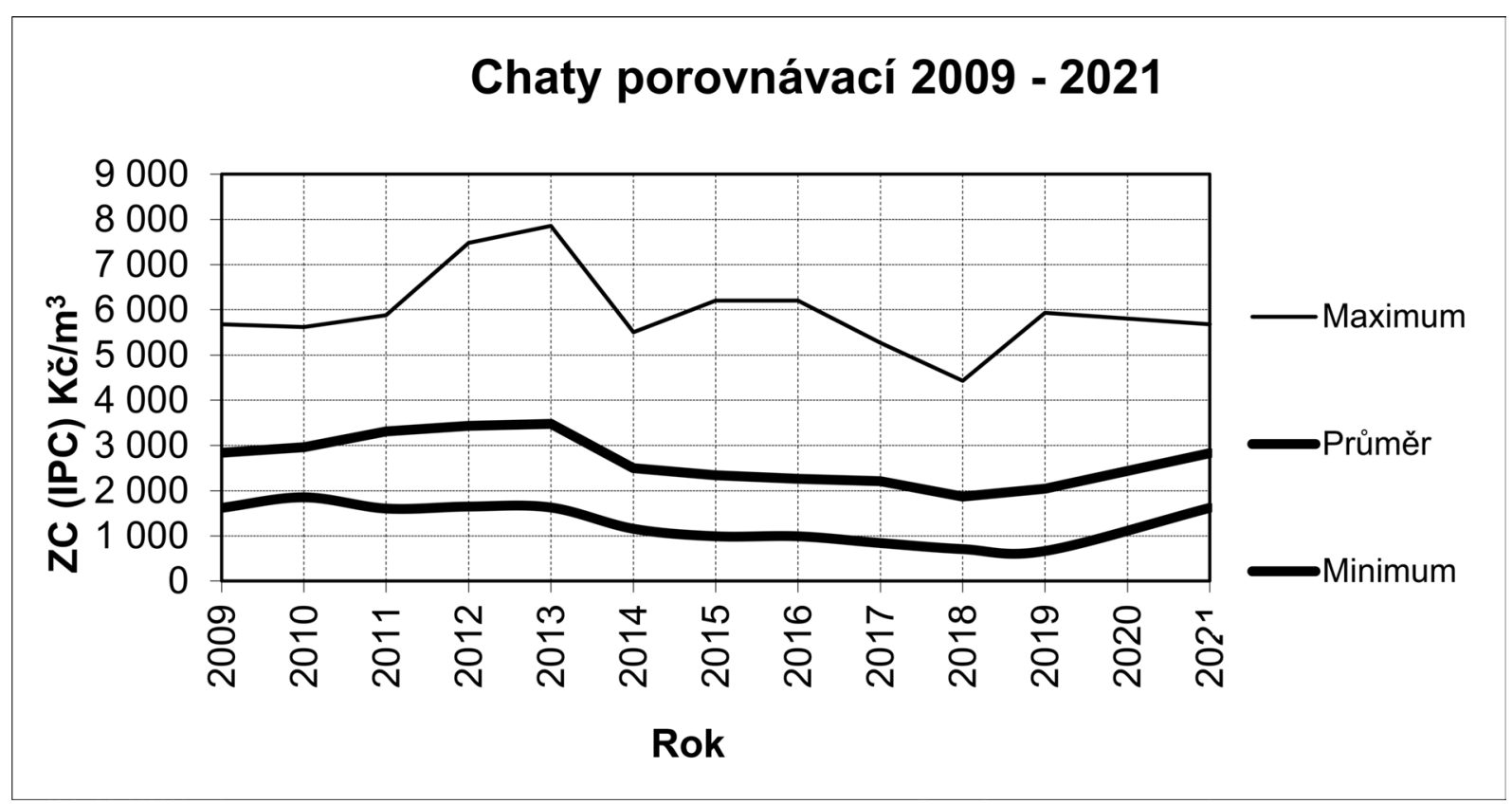

Obr. 6 Vývoj základnich cen ZC u porovnávaci metody v letech 2009-2021; rekreačni a zahrádkářské chaty. Fig. 6 Evolution of basic prices ZC with comparative methods in the years 2009-2021; recreational and gardening cottages. 


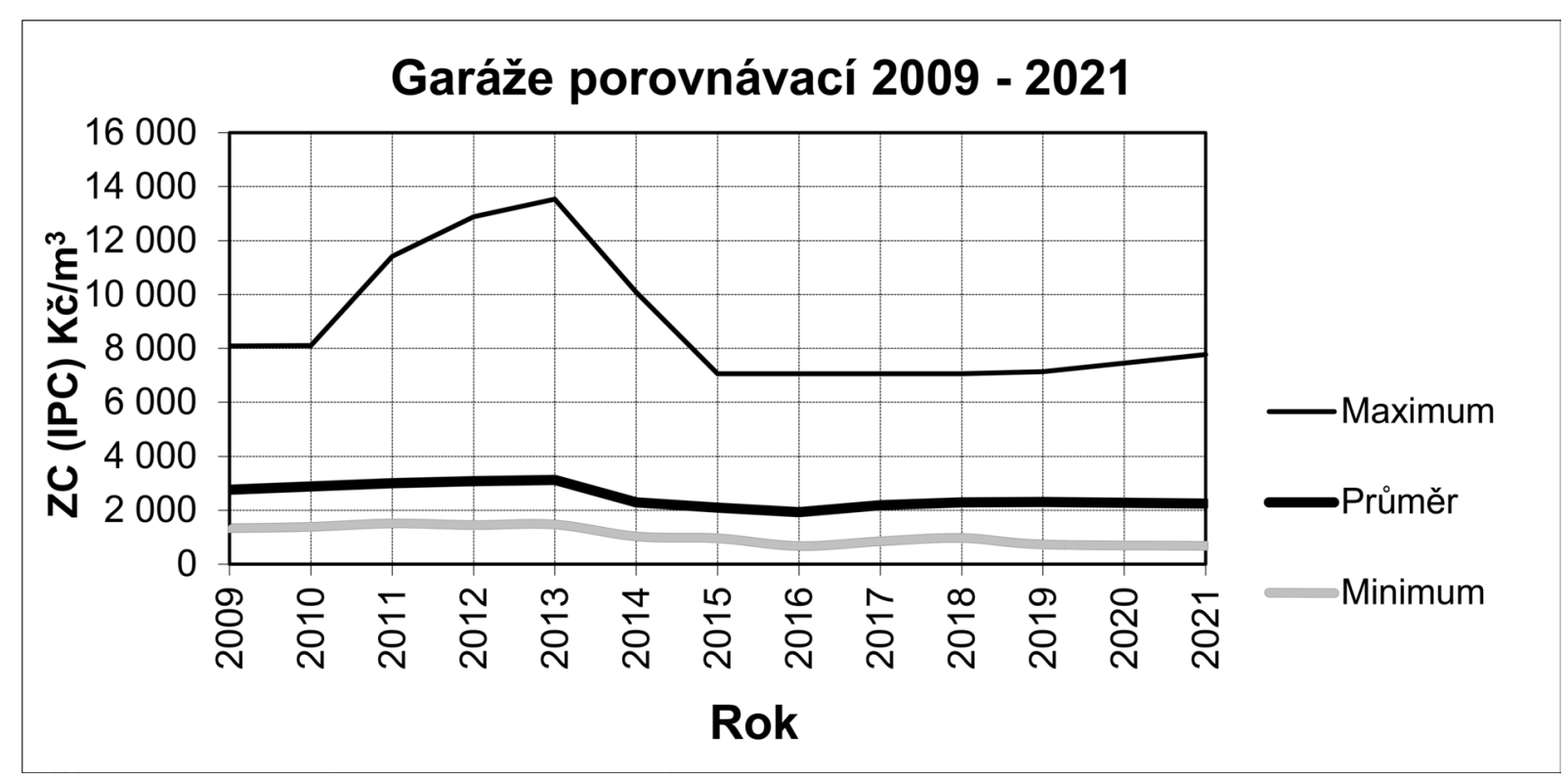

Obr. 7 Vývoj základnich cen ZC u porovnávací metody v letech 2009-2021; garáže.

Fig. 7 Evolution of basic prices ZC with comparative methods in the years 2009-2021; garage.

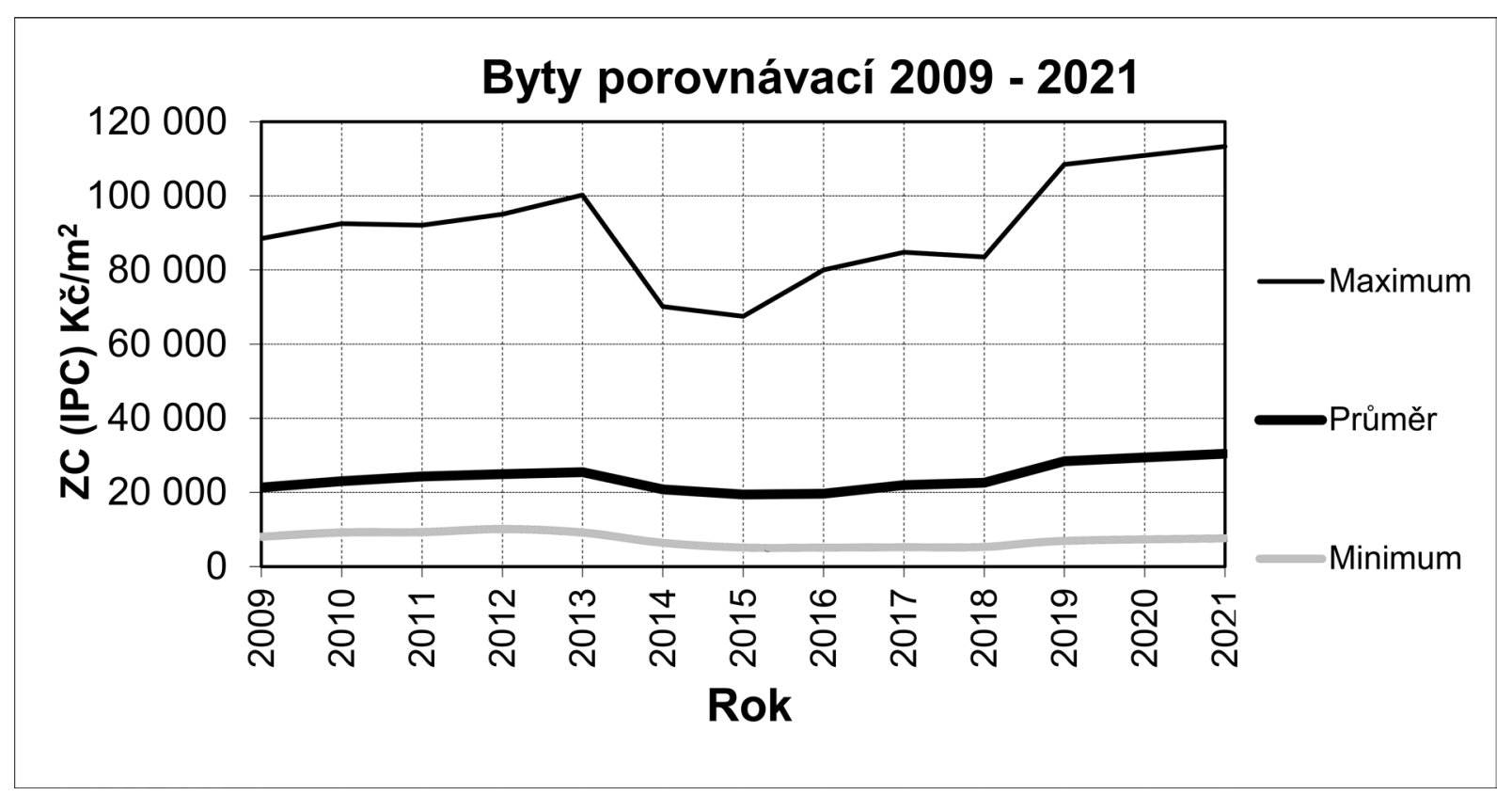

Obr. 8 Vývoj základních cen ZC u porovnávací metody v letech 2009-2021; byty.

Fig. 8 Evolution of basic prices ZC with comparative methods in the years 2009-2021; flats. 


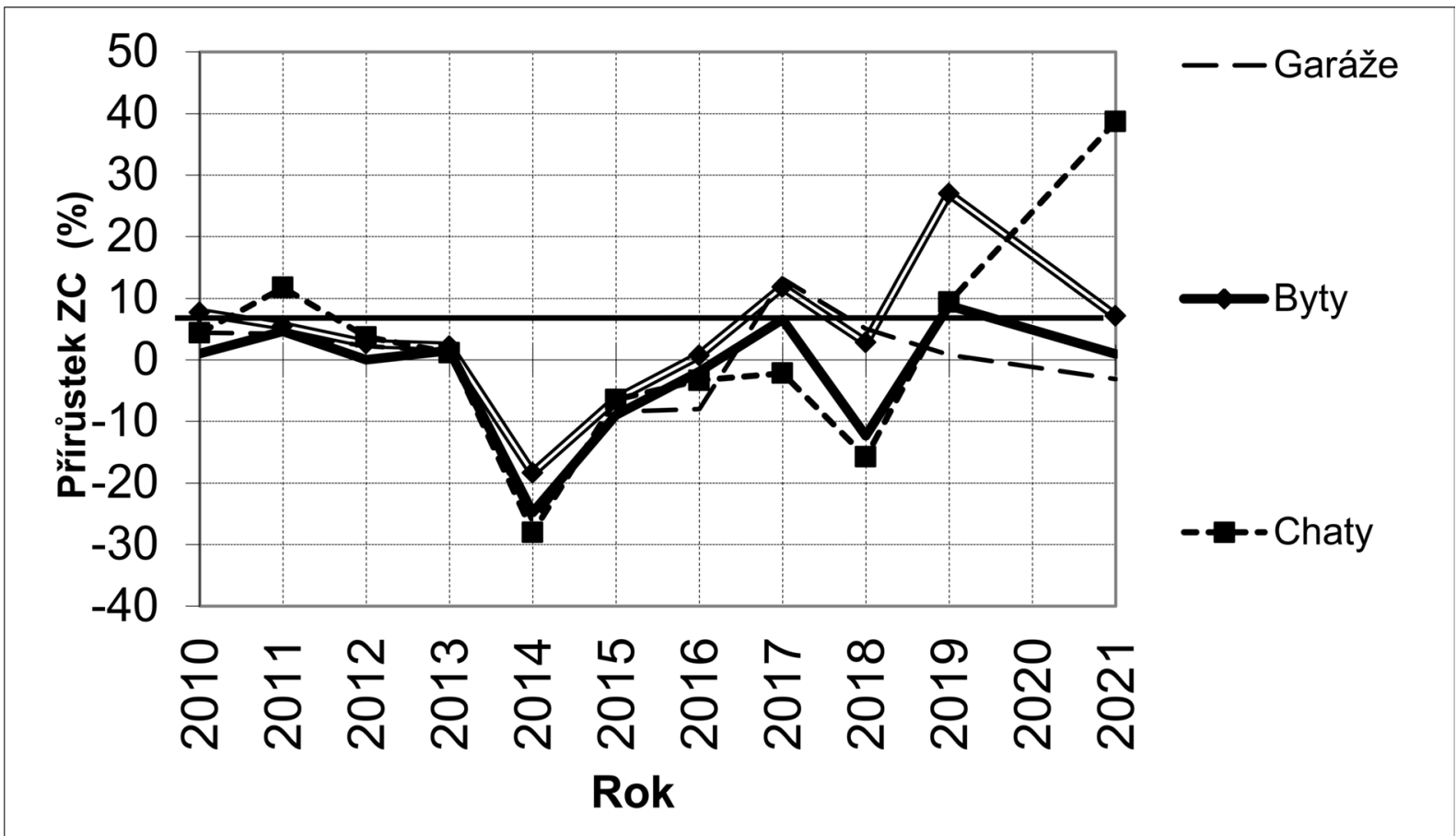

Obr. 9 Vývoj meziročního prírůstku průmèru základni ceny u porovnávací metody v letech 2010-2021.

Fig. 9 Evolution of annual increase in the average basic price by comparison methods in the years 2010-2021.

Tab. 2 Přehled meziročních prírůstků průměru ze základních cen u porovnávacího způsobu ocenění v letech 2010-2021.

Tab. 2 Overview of annual growth averages from basic prices by reference to the valuation in the years 2010-2021.

\begin{tabular}{lcccccccccccc}
\hline \multicolumn{7}{c}{ Př́růstek průměru ze ZC u porovnávacího způsobu ocenění staveb v daném roce oproti roku předchozímu (\%) } \\
\hline Rok & 2010 & 2011 & 2012 & 2013 & 2014 & 2015 & 2016 & 2017 & 2018 & 2019 & 2021 \\
Garáže & 4,45 & 4,23 & 2,26 & 1,46 & $-26,46$ & $-8,45$ & $-7,99$ & 13,13 & 5,03 & 0,78 & $-3,12$ \\
Byty & 7,68 & 5,54 & 2,67 & 2,19 & $-18,34$ & $-6,4$ & 0,74 & 11,8 & 2,86 & 26,95 & 7,14 \\
Chaty & 4,39 & 11,74 & 3,73 & 1,18 & $-28,0$ & $-6,43$ & $-3,31$ & $-2,16$ & $-15,75$ & 9,39 & 38,70 \\
$\begin{array}{l}\text { Rodinné domy, rekreační } \\
\text { chalupy a domky }\end{array}$ & 1,05 & 4,62 & 0,02 & 1,55 & $-24,8$ & $-8,96$ & $-1,93$ & 6,58 & $-12,29$ & 8,82 & 0,97 \\
\hline
\end{tabular}

\section{Oceňování věcného břemene}

Pod pojem věcného břemene patří

- služebnosti (§ 1257 a násl. občanského zákoníku) postihují vlastníka věci jako věcné právo tak, že vlastník musí ve prospěch jiného něco trpět nebo něčeho se zdržet, a

- reálná břemena ( $\$ 1303$ a násl.) - je-li věc zapsána do veřejného seznamu, může být zatížena reálným břemenem tak, že dočasný vlastník věci je jako dlužník zavázán vůči oprávněné osobě něco jí dávat nebo něco konat.

Dle ustanovení §16b zákona č. 151/1997 Sb., o oceňování majetku, ve znění pozdějších předpisů, se dosud při výpočtu ceny věcného břemene uplatňoval výnosový způsob ocenění metodou věčné renty na základě ročního užitku oprávněného z věcného břemene a počtu let jeho trvání. Nově se věčná renta bude používat pouze $\mathrm{v}$ případech, kdy věcné břemeno bylo zrrízeno na dobu neurčitou nebo pokud nelze objektivně určit dobu jeho trvání (např. při sjednané rozvazující podmínce). V ostatních případech se pro výpočet použije určení současné hodnoty budoucích př́ijmů, což umožňuje objektivnější př́istup k určení ceny věcného břemene. Navrhovaná metoda výpočtu vychází z doby dalšího trvání věcného břemene, a to jak pro služebnost, tak i pro reálné břemeno. S výjimkou vykupitelných služebností a reálných věcných břemen zřízených na dobu neurčitou, u nichž se cena určí z ujednání ze smlouvy o zřízení věcného břemene, jak určuje občanský zákoník, která se oceňují podle $§ 16$ b odst. 4 zákona č. 151/1997 Sb., ve znění včetně jeho poslední novely provedené zákonem č. 237/2020 Sb., který nabývá účinnosti dne 1. 1. 2021. A dále s výjimkou zjednodušeného ocenění podle $\S 39 \mathrm{~b}$.

V zákonu o oceňování majetku je tedy novelizován $\S 16 \mathrm{~b}$ o oceňování věcných břemen a nově je přidán $\S 16 \mathrm{c}$, definující ocenění závady na nemovité věci (a naopak stanoví, která práva závadami nejsou): 


\section{$\S 16 b-$ Oceňování věcných břemen}

(1) Věcné břemeno se oceňuje výnosovým zpưsobem na základě ročního užitku při zohledněni doby jeho trvání nebo pevnou částkou, nelze-li určit roční užitek z věcného břemene.

(2) U služebnosti se v ročním užitku zohledňuje míra omezení uživání nemovité věci.

(3) U reálného bremene zohledňuje ročni užitek prospěch oprávněného.

(4) Časově neomezené reálné bremeno nebo právo z vykupitelné služebnosti se ocení ve výši náhrady uvedené ve smlouvě. Jsou-li ve smlouvě uvedené pouze podminky výkupu reálného břemena nebo zrušení služebnosti za přiměřenou náhradu, vypočte se náhrada podle uvedených podmínek $k$ datu ocenění.

(5) Zpưsob členění věcných břemen podle výpočtu jejich ocenění, postup výpočtu ceny věcného bremene, způsob určení ročního užitku a miry kapitalizace podle druhu věcného břemene a zatižené nemovité věci a výši pevné částky stanoví vyhláška.

(6) Ocenění podle odstavců 2 až 4 se nepoužije, lze-li cenu věcného břemene zjistit z rozhodnutí př̀islušného orgánu.

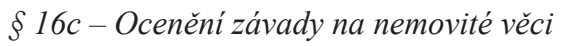

(1) Zatěžuje-li nemovitou věc věcné břemeno nebo právo zř̉zené jinak než jako právo odpovidající věcnému břemenu (dále jen „závada“), snižuje cena této závady v prípadě určováni ceny nemovité věci jeji hodnotu. Závada se oceňuje v závislosti na výši ceny ročni újmy vlastnika nemovité věci souvisejicís tímto zatižením při zohledněni doby jejiho trvání.

(2) Pro účely tohoto zákona se za závadu nepovažuje

a) právo, které podstatně neomezuje vlastnické, uživací nebo poživací právo $k$ nemovité věci a nemá tak významný vliv na výši jeji ceny,

b) zástavní právo,

c) nájem,

d) pacht,

e) právo stavby.

(3) Výše ročni újmy se urči jako rozdíl mezi výši ročního užitku plynoucího z nemovité věci bez zatiženi závadou a výši ročního užitku z nemovité věci se zatižením závadou.

(4) Pro určení ročního užitku vlastnika nemovité věci a zpưsobu jeho výpočtu se použije postup podle § 16 bobdobně. Postup oceněni závady, stanovení míry kapitalizace podle druhu závady a zatižené nemovité věci stanoví vyhláška.

V oceňovací vyhlášce pak byly přidány $\S \S 39 \mathrm{a}$ až 39c, rozvíjející tato ustanovení, stanovící zjednodušené ocenění věcného břemene pro technickou infrastrukturu a upřesňující oceňování závady na nemovité věci, a to podle nsledujícího schematu:

- Věcné břemeno na dobu neurčitou: $\$ 39$ a odst, 1 písm, a) (příklad v tab. 3); Výjimka: zjednodušené ocenění věcného břemene pro technickou infrastrukturu (viz níže).

- Věcné břemeno na dobu určitou nebo na délku života: § 39a odst, 1 písm, b) (př́klad VB užívání bytu na délku života $\mathrm{v}$ tab. 4).

- Roční užitek z věcného břemene: $§ 39$ a odst. 2.

- Počet let dalšího trvání věcného břemene: § 39a odst. 3.

- Ocenění věcného břemene pro technickou infrastrukturu$\S 39 b$. Týká se věcného břemene při umístění podzemního vedení technické infrastruktury do silničního nebo pomocného silničního pozemku, pokud je zřizeno na dobu neurčitou (př́klad v tab. 5).
- Závady na nemovité věci: $§ 39 \mathrm{c}$.

$\$ 39 a-$ Oceňování věcného břmene

(1) Cena věcného bremene se určuje v závislosti na počtu let jeho dalšiho trváni a ročního užitku oprávněného, kromě časově neomezeného reálného bremene a vykupitelné služebnosti. Je-li věcné břemeno zrízeno na dobu

a) neurčitou, cena věcného břemene, s výjimkou zjednodušeného oceněni věcného bremene pro technickou infrastrukturu podle $\S 39 b$, se urči podle vzorce

$$
C B_{N}=\frac{r u_{o}}{p},
$$

kde:

$C B_{N} \quad$ cena věcného bremene zř́zeného na dobu neurčitou $v K \check{c}$,

ru $\quad$ roční užitek oprávněného $z$ věcného bremene $v$ Kč, určený podle odstavce 2,

p míra kapitalizace podle prílohy č. $22 \mathrm{k}$ této vyhlášce, v setinném vyjádření,

b) určitou nebo na dobu života, cena věcného břemene se určl podle vzorce

$$
C B_{U}=r u_{o} \times \frac{(1+p)^{n}-1}{(1+p)^{n} \times p}
$$

kde:

$C B_{U} \quad$ cena věcného bremene zřizeného na dobu určitou nebo na dobu života $v$ Kč,

ru $\quad$ ročni užitek oprávněného $z$ věcného bremene $v$ Kč, určený podle odstavce 2,

p míra kapitalizace podle př́lohy č. $22 k$ této vyhlášce, v setinném vyjádření,

$n \quad$ počet let dalšiho trvání věcného bremene určený podle odstavce 3.

(2) Ročni užitek oprávnèného z věcného břemene se urči jako součet všech dillčich ročních užitki̊, které plynou oprávněnému $z$ věcného bremene, podle vzorce

$$
r u_{o}=\sum_{i=1}^{n}\left(r u_{i} \times k o_{i}\right)
$$

$k d e$ :

$r u_{o} \quad$ roční užitek oprávněného $z$ věcného břemene $v$ Kč,

$\mathrm{ru}_{i} \quad$ dilči ročni užitek oprávněného $z$ věcného břemene $z$ nemovité věci nebo jeji části zatižené věcným bremenem v Kč, který se obvykle zjistí pro ocenèni

a) služebnosti pozemkové s výjimkou věcného bremene pro technickou infrastrukturu podle $\S 39 b$, nebo uživacího práva, poprípadě obdobného práva z ročního obvyklého nájemného určeného podle § la plynoucího ze zatížené nemovité věci nebo její části se zohledněním prípadných nákladi̊ na zachování a opravu zatǐzené nemovité věci, které nese oprávněný; obvyklé nájemné se urči vynásobením počtu měrných jednotek nemovité věci zatižených služebností ročním obvyklým nájemným za měrnou jednotku v Kč; $u$ věcného břmene pro technickou infrastrukturu a pokud nelze $v$ ostatnich př́padech obvyklé nájemné 
$z$ nemovité věci zjistit, se vycházi při určeni ročního užitku ze simulovaného nájemného, které se urči ve výši $5 \%$ ze zjištěné jednotkové základni ceny upravené věcným břemenem zatižené nemovité věci, určené dle oceňovaci vyhlášky; od takto zjištěného nájemného se odečte obvyklá cena nákladi̊ na zachováni a opravu zatížené nemovité věci, které nese oprávněný,

b) služebnosti požívacího práva, ze součtu dillčiho ročního užitku oprávněného určeného podle písmene a) a dilč́iho ročního užitku ve výši obvyklé ceny plodi̊ a užitků vzešlých ze zatižené nemovité věci za rok touto služebností, při zohledněni obvyklých dosažitelných výnosů a užitků, a odpočtu nákladů, bez nichž by se plodů a užitku nedosáhlo, neni-li ve smlouvě uvedeno jinak,

c) reálného břemene, z ročního prospěchu plynoucího ze závazku, kterýje vlastník nemovité věci povinen poskytovat oprávněnému; u naturálniho plněni nebo poskytované služby se urči ve výši obvyklé ceny určené podle § la v rozsahu podle smlouvy, pokud nebyl ve smlouvě určen, pak podle běžné zvyklosti,

pořadové číslo dilčího ročního užitku plynoucího $z$ věcného bremene,

$n$ počet dillčich ročních užitků plynoucí z věcného břemene.

$k_{i} \quad$ koeficient miry užitku, který zohledňuje podil oprávněného z věcného břemene na ročním užitku plynoucím z nemovité věci vlastnikovi a míru omezení vlastnika věci, vyjadřje způsob a četnost využiváni nemovité věci oprávněným. Koeficient míry užitku se určuje podle účelu uživání zatižené nemovité věci věcným bremenem oprávněným.

Pokud

a) oprávněný nemovitou věc uživá shodně s jejím účelem užití, hodnota koeficientu se urči jako podíl na uživání nebo spoluuživáni nemovité věci oprávněným,

b) oprávněný nemovitou věc využivá $k$ jinému účelu, než ke kterému je nemovitá věc určena a skutečně uživána, hodnota koeficientu se urči ve výši omezení uživáni vlastnika v souvislosti s tímto zatižením,

c) se jedná o věcné břemeno pro technickou infrastrukturu, a to na dobu neurčitou, urči se hodnota koeficientu podle tabulky č. 2 přilohy č. 22 a k této vyhlášce.

(3) Počet let dalšiho trvání věcného břemene se určí jako doba, která uplyne od roku, ke kterému se oceněni provádi, do zániku věcného břemene. Nelze-li datum zániku věcného břemene ze smlouvy o zř́zení věcného břemene určit, vyjma věcného břemene zř́zeného na dobu života, má se za to, že bylo zřizeno na dobu neurčitou. V prípadě, že se jedná o

a) osobni věcné bremeno sjednané na dobu života, průměrný počet let dalšiho trváni věcného břemene n se urči z tabulky č. 3 př́lohy č. 22 a $k$ této vyhlášce podle věku oprávněného $k$ datu oceněni, b) časově neomezenou osobni služebnost, kde oprávněnou osobou je právnická osoba, má se za to, že služebnost byla sjednána na dobu neurčitou,

c) služebnost opory cizi stavby, počet let dalšiho trváni věcného bremene se urči podle dalši životnosti stavby nebo konstrukce, která je zatižena touto služebností.

(4) Nelze-li cenu věcného břemene zjistit podle odstavců 1 až 3, oceňuje se peněžní částkou ve výši 10000 Kč.

(5) Právo zrrizené jinak než věcným břemenem obdobné služebnosti nebo reálnému břemenu se oceňuje podle odstavců $1 a z ̌ 4$.

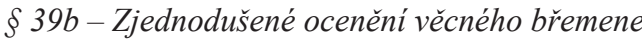 pro technickou infrastrukturu}

(1) Zjednodušené ocenění věcného břemene pro technickou infrastrukturu se použije pro umistěni podzemniho vedeni technické infrastruktury do silničního nebo pomocného silničniho pozemku, pokud jsou zř́zena na dobu neurčitou. Cena se určuje v závislosti na umístèní vedení na těchto pozemcích, a to podle vzorce

$$
C B_{Z}=r u_{z} \times d \times k_{u} \text {, }
$$

kde:

$C B_{Z}$....cena věcného bremene pro technickou infrastrukturu $v$ Kč určená zjednodušeným způsobem,

$r u_{z}$......ročni užitek oprávněného $v$ Kč za $m$ z věcného břemene pro podzemni technickou infrastrukturu, který se urči podle vzorce

$$
r u_{z}=Z C \times 0,015,
$$

kde:

ZC základní cena stavebního pozemku v Kč za $1 \mathrm{~m}^{2}$ určená podle § 3 ,

0,015 konstanta,

$d \quad$ délka vedeni technické infrastruktury $v$ m,

$k_{u} \quad$ koeficient miry užitku a omezení vlastnika nemovité věci pro zjednodušené ocenéní věcného břemene pro technickou infrastrukturu, který se urči podle tabulky č. 1 prrilohy č. 22 a $k$ této vyhlášce, $v$ závislosti na umisténí vedení v silničním pozemku nebo pomocném silničním pozemku, a který zohledňuje širri technické infrastrutury.

(2) Hodnota ročního užitku činí nejméně 10 Kč za 1 m a nejvíce $1500 \mathrm{Kčza} 1 \mathrm{~m}$.

$\S 39 c-$ Oceňováni závady na nemovité věci

(1) Celková cena závad zatěžujících nemovitou věc se určuje $v$ závislosti na počtu let jejího dalšiho trvání, podle vzorce

$$
C Z=\sum_{i=1}^{n} C Z_{n_{i}}+\sum_{i=1}^{u} C Z_{u_{i}}
$$

kde:

CZ celková cena závad zatěžujicich nemovitou věc $v K \check{c}$,

n počet dilčich závad pripadajícich na dobu neurčitou,

u počet dilčich závad pripadajicich na dobu určitou nebo dobu života oprávněného,

$C Z_{n_{i}} \quad$ cena i-té dilčí závady na dobu neurčitou $v$ Kč, kromě časově neomezeného reálného břemene a vykupitelné služebnosti, která se urči podle vzorce 


$$
\begin{aligned}
& C Z_{n_{i}}=\frac{r j_{v}}{p}, \\
& C Z_{u_{i}}=r j_{v} \times \frac{(1+p)^{k}-1}{(1+p)^{k} \times p},
\end{aligned}
$$

odstavce 3, nebo počet let trvání určený v závislosti na době života oprávněného $k$ datu oceněni, určeném podle tabulky č. 3 prílohy č. 22 a k této vyhlášce.

(2) Dílči ročni újma vlastníka nemovité věci ze závady rj, se urči jako rozdíl mezi výši dillčiho ročního užitku plynoucího z nemovité věci bez zatížení závadou a výši dillčiho ročního užitku z nemovité věci se zatížením závadou. V prípadě, že dilč́i roční újma vlastníka

\begin{tabular}{|c|c|c|c|}
\hline \multicolumn{4}{|l|}{ Výpočet ceny věcného břemene chůze a jízdy, na dobu neurčitou } \\
\hline \multicolumn{4}{|c|}{ (Předcházi identifikace - podrobný popis nemovité věci a druhu věcného břemene) } \\
\hline \multicolumn{4}{|l|}{ Stanovení ročního užitku oprávněného z VB } \\
\hline Základní cena stavebního pozemku podle tabulky č. 1 a č. 2 př́lohy č. 2 oceňovací vyhlášky & $Z C$ & $\mathrm{Kč} / \mathrm{m}^{2}$ & 229,00 \\
\hline Délka plochy dotčené věcným břemenem & $d$ & $\mathrm{~m}$ & 20,00 \\
\hline Šířka plochy dotčené věcným břemenem & $\check{s}$ & $\mathrm{~m}$ & 3,00 \\
\hline Dotčená plocha & $S$ & $\mathrm{~m}^{2}$ & 60,00 \\
\hline Obvyklé nájemné jednotkové ročně & & $\mathrm{Kč} / \mathrm{m}^{2} /$ rok & 30,00 \\
\hline Obvyklé nájemné celkem ročně & $r u_{1}$ & Kč/rok & 1800,00 \\
\hline Podíl užívání oprávněným & & $\%$ & 30,00 \\
\hline Koeficient míry užitku (vyjadřuje způsob a četnost využívání nemovité věci oprávněným) & $k o_{i}$ & & 0,30 \\
\hline Roční užitek č. 1 oprávněného z věcného břemene po zohlednění míry užitku & & Kč/rok & 540,00 \\
\hline $\begin{array}{l}\text { Náklady na zachování a opravu zatížené nemovité věci, které nese oprávněný - odpočet (v daném } \\
\text { př́padě náklady podle smlouvy nenese oprávněný žádné) }\end{array}$ & & $\mathrm{Kč} /$ rok & 0,00 \\
\hline $\begin{array}{l}\text { Roční užitek č. } 1 \text { oprávněného z věcného břemene po zohlednění míry užitku a nákladů } \\
\text { na zachování a opravy }\end{array}$ & $r u_{1}$ & $\mathrm{Kč} /$ rok & 540,00 \\
\hline (Další ev. roční užitky oprávněného z věcného břemene obdobně) & & $\mathrm{Kč} /$ rok & 0,00 \\
\hline Roční užitek podle $\S 39 \mathrm{~b}$ odst. 2 celkem $\left(r u_{\mathrm{o}}=\Sigma\left(r u_{\mathrm{i}} \times k o_{\mathrm{i}}\right)\right.$ & $r u_{o}$ & $\mathrm{Kč} /$ rok & 540,00 \\
\hline \multicolumn{4}{|l|}{ Stanovení ceny věcného břemene } \\
\hline Druh nemovité věci, kterou věcné břemeno zatěžuje & \multicolumn{3}{|c|}{ Pozemek ve $\mathrm{FC}$ u rodinného domu } \\
\hline Míra kapitalizace podle př́lohy č. 22 k oceňovací vyhlášce, řádek 10 & $p$ & $\%$ & 4,5 \\
\hline dtto v setinném vyjádření & $p$ & - & 0,045 \\
\hline Cena věcného břemene na dobu neurčitou $C B_{N}=r u_{o} / p$ & $C B_{Z}$ & Ǩ̆ & 12000,00 \\
\hline
\end{tabular}
nemovité věci odpovidá dillčimu ročnímu užitku oprávněného $z$ věcného břemene, postupuje se obdobně podle $\$ 39$ a odst. 2.

(3) Počet let dalšiho trvání závady se urči jako doba, která uplyne od roku, ke kterému se ocenéni provádí, do zániku závady. Je-li závadou věcné bremeno, pak se počet let dalšiho trváni urči podle § $39 a$ odst. 3. Vostatnich prípadech dalšiho trvání závady se postupuje obdobně.

(4) Celková cena souhrnu závad zatěžujicich nemovitou věc nesmí činit více jak $80 \%$ určené ceny nemovité věci.

Ustanovení § 39a odst. 2 upravuje obecný postup určení ročního užitku pro oprávněného z věcného břemene. Vychází se přitom z rozsahu a obsahu věcného břemene, které určuje primárně smlouva nebo rozhodnutí orgánu veřejné moci. Není-li ve smlouvě rozsah závazku jednoznačně určen, jsou rozhodující místní zvyklosti nebo se rozsah služebnosti řídí potřebou panující nemovitosti $\mathrm{v}$ době sjednání věcného břemene. Zohlednění nákladů na zachování a opravy zatížené nemovité věci se uplatní

Tab. 3 Algoritmus oceněni věcného břemene na dobu neurčitou podle § 39 a oceňovací vyhlášky.

Tab. 3 Algorithm for valuing easements for an indefinite period according to $\$ 39$ a of the valuation decree.

Př́klad: věcné břemeno práva přechodu nebo přejezdu (chůze a jízdy) přes pozemek parc. č. 111, druh: zastavěná plocha a nádvoří, zpưsob využití: zahrada (u RD) na pozemek parc. č. 112, druh: zahrada, zpưsob využití: zahrada. Na dobu neurčitou. Délka $20 \mathrm{~m}$, šírka $3 \mathrm{~m}$. 
Tab. 4 Algoritmus oceněni věcného břemene na délku života podle \$39a oceňovací vyhlášky.

Tab. 4 Algorithm for valuing easements for life expectancy according to $\$ 39$ a of the valuation decree.

Přiklad: oprávněná ve věku 28 let, věcné břemeno doživotního bydlení jako jediná uživatelka v bytu o výměre $72 \mathrm{~m}^{2}$. Podle smlouvy neni povinna podilet se na nákladech na zachováni a opravy bytu. Na délku života, Obvyklá cena bytové jednotky v domě bytovém typovém vč. príslušenství čini 1.150.000,-Kč.

\section{Výpočet ceny věcného břemene}

(Předchází identifikace - podrobný popis nemovité věci a druhu věcného břemene)

\begin{tabular}{|c|c|c|c|}
\hline \multicolumn{4}{|l|}{ Stanovení ročního užitku oprávněného z VB, zřízeného na dobu života } \\
\hline $\begin{array}{l}\text { Obvyklé nájemné daného bytu měsíčně (nelze-li zjistit, postupuje se přes } 5 \% \text { z ceny bytu postupem } \\
\text { podle } \S 39 \mathrm{a} \text { odst. } 2 \text { položka } r u_{\mathrm{i}} \text { písm. a)) }\end{array}$ & & Kč/měsíc & 8000,00 \\
\hline Obvyklé nájemné ročně & & $\mathrm{Kč} /$ rok & 96000,00 \\
\hline $\begin{array}{l}\text { Obvyklé nájemné jednotkové (dílčí roční užitek oprávněného } \mathrm{z} \text { věcného břemene z nemovité věci } \\
\text { nebo její části zatížené věcným břemenem pro vyjmenované prípady) }\end{array}$ & & $\mathrm{K} \check{c} / \mathrm{m}^{2} / \mathrm{měsíc}$ & 111,11 \\
\hline Roční užitek č. 1 oprávněného $\mathrm{z}$ věcného břemene & $r u_{i .}$ & Kč/rok & 96000,00 \\
\hline Podíl užívání bytu oprávněnou & & $\%$ & 100 \\
\hline Koeficient míry užitku (vyjadřuje způsob a četnost využívání nemovité věci oprávněným) & $k o_{i}$ & & 1,00 \\
\hline Roční užitek č. 1 oprávněné z věcného břemene po zohlednění míry užitku & & Kč/rok & 96000,00 \\
\hline $\begin{array}{l}\text { Náklady na zachování a opravu zatížené nemovité věci, které nese oprávněná - odpočet (v daném } \\
\text { případě náklady podle smlouvy nenese oprávněný žádné) }\end{array}$ & & Kč/rok & 0,00 \\
\hline $\begin{array}{l}\text { Roční užitek č. } 1 \text { oprávněného z věcného břemene po zohlednění míry užitku a nákladů } \\
\text { na zachování a opravy }\end{array}$ & $r u_{1}$ & $\mathrm{Kč} /$ rok & 96000,00 \\
\hline Další roční užitky oprávněné z věcného břemene obdobně & & Kč/rok & 0,00 \\
\hline Roční užitek podle $\S 39 \mathrm{~b}$ odst. $2\left(r u_{\mathrm{o}}=\Sigma\left(r u_{\mathrm{i}} \mathrm{x} k o_{\mathrm{i}}\right)\right.$ & $r u_{o}$ & Kč/rok & 96000,00 \\
\hline Druh nemovité věci, kterou věcné břemeno zatěžuje & & Bytový dům & ový (J) \\
\hline Míra kapitalizace podle př́lohy č. 22 k oceňovací vyhlášce, řádek 13 & $p$ & $\%$ & 5,5 \\
\hline dtto v setinném vyjádření & $p$ & - & 0,055 \\
\hline Stáří oprávněné & & let & 28 \\
\hline Průměrný počet let dalšího trvání věcného břemene (příl. 22a, tab. 3) & $n$ & let & 56,00 \\
\hline Pomocné: úročitel & $q$ & $=1+\mathrm{p}$ & 1,055 \\
\hline Pomocné: n-tá mocnina úročitele & $q^{n}$ & $\mathrm{q}^{\mathrm{n}}=(1+\mathrm{p})^{\mathrm{n}}$ & 20,051079 \\
\hline Cena věcného břemene na dobu určitou $C B_{U}=r u_{o} \times\left(q^{n}-1\right) /\left(q^{n} x p\right)$ & $C B_{U}$ & & 1658404,14 \\
\hline
\end{tabular}

i v př́ípadech, které nejsou uvedeny ve smlouvě; smluvně nelze postihnout všechny př́ípady, které mohou ve skutečnosti nastat. Dílčí roční užitek oprávněného nemusí být vždy kladný. Roční užitek se pro oprávněného určuje ve výši obvyklého nájemného z nemovité věci. Je-li služebnou věcí pozemek zatížený věcným břemenem pro technickou infrastrukturu a nelze-li obvyklé nájemné objektivně určit, pak se roční užitek určí jako podíl ve výši $5 \%$ z ceny zjištěné zatíženého pozemku (tzv. simulované nájemné). $\mathrm{V}$ případě požívacího práva oprávněný nejen užívá nemovitou věc, ale i bere z této věci plody a užitky, bude-li zachována podstata věci, např. zemědělské výpěstky, atd. Proto $\mathrm{v}$ př́padě požívacího práva se do ročního užitku zahrne i cena těchto plodů a užitků získaná ze zatížené nemovité věci za rok. V prŕípadě reálných břemen, kdy vlastník nemovité věci musí něco konat nebo poskytovat oprávněnému určitou službu nebo důchod, se při určení ročního užitku vychází z obvyklých cen za roční plnění. Věcná břemena, jako např. u výměnku, mohou být kombinací poskytování služby a strpění užívání nemovité věci oprávněným. Celkový roční užitek se pak určí jako součet všech dílčích užitků příslušející oprávněnému. Obdobně se postupuje i v případech, jedná-li se o nezbytnou cestu a věcné právo vznikající ze zákona.
Samostatně je upraveno určení ročního užitku pro služebnost inženýrské sítě nebo věcné břemeno pro technickou infrastrukturu, které jsou zřizovány podle zákona.

Koeficient míry služebnosti zohledňuje způsob užívání zatížené nemovité věci oprávněným. Je-li nemovitá věc ve spoluužívání oprávněného a vlastníka nemovité věci (nebo další osoby), rozdělí se roční užitek v poměru spoluuživání. Při jejím určení se vychází ze stavu, který byl v době zřízení věcného břemene (ke změnám $\mathrm{v}$ průběhu věcného břemene se nepřihlížíi). $\mathrm{V}$ případech, kdy oprávněný využívá nemovitou věc jiným způsobem, než k jakému je určena, pak roční užitek je třeba určit jako doplněk mezi ročním užitkem jejího vlastníka před jejím zatížením a ročním užitkem vlastníka po jejím zatížení, tzn., roční užitek, který získává oprávněný.

Odstavec 3 § 39a upravuje postup určení dalšího trvání věcného břemene. Doba dalšího trvání věcného břemena zřízeného na dobu života nově vychází ze statistického vyhodnocení délky života (délky dožití) podle věku oprávněného, které je zveřejňováno na stránkách Českého statistického úřadu. Určení délky trvání věcného břemene podle věku oprávněného přispívá k objektivitě ocenění uplatňovaného i v tržním ocenění. Současně dochází 
Tab. 5 Algoritmus ocenění věcného břemene pro technickou infrastrukturu zjednodušeným způsobem podle §39b oceňovací vyhlášky.

Tab. 5 Algorithm for valuing easements for technical infrastructure in a simplified manner according to $\$ 39 b$ of the valuation decree.

\begin{tabular}{lc}
\hline \multicolumn{2}{c}{ Př́klad zjednodušeného ocenění věcného břemene pro technickou infrastrukturu na dobu neurčitou $-\S 39 b$} \\
\hline Kraj & Popis věcného břemene \\
Okres & Liberecký \\
Obec & Česká Lípa \\
Č́st obce & Nový Bor \\
Katastrální území - název & Nový Bor \\
Katastrální území - číslo & Nový Bor \\
List vlastnictví č. & 707155 \\
Parcela č. & 1 \\
Druh pozemku dle KN & 1 \\
Způsob využití dle KN & ostatní plocha \\
Skutečný způsob využití & jiná plocha \\
\hline
\end{tabular}

Popis: VB plynovodního řadu STL DN 200 přes křižovatku komunikací Nový Bor - Česká Lípa a Nový Bor - Skalice u České Lípy. Na dobu neurčitou.

\begin{tabular}{|c|c|c|c|}
\hline \multicolumn{4}{|c|}{ Výpočet ceny věcného břemene } \\
\hline \multicolumn{4}{|c|}{ Stanovení ročního užitku oprávněného z VB pro podzemní technickou infrastrukturu $r u_{\mathrm{z}} \mathrm{v}$ Kč/m } \\
\hline Základní cena stavebního pozemku podle tabulky č. 1 a č. 2 př́lohy č. 2 & $Z C$ & $\mathrm{Kč} / \mathrm{m}^{2}$ & 439,00 \\
\hline Konstanta podle $\S 39 \mathrm{~b}$ odst. 1 & - & & 0,015 \\
\hline Roční užitek oprávněného $\left(r u_{\mathrm{z}}=\mathrm{ZC} \times 0,015\right)$ & $r u_{z}$ & $\mathrm{Kč} / \mathrm{m} . \mathrm{r}$ & 6,59 \\
\hline Roční užitek minimum ( $(39 \mathrm{~b}$ odst. 2) & $r u_{z \min }$. & & 10,00 \\
\hline Roční užitek maximum ( $(39 \mathrm{~b}$ odst. 2) & $r u_{z \max }$. & & 1500,00 \\
\hline Roční užitek podle $\S 39 \mathrm{~b}$ odst. 1 & $r u_{z}$ & $\mathrm{Kč} / \mathrm{m}$ & 10,00 \\
\hline
\end{tabular}

Stanovení koeficientu míry užitku a omezení vlastníka nemovité věci pro zjednodušené ocenění věcného břemene pro technickou infrastrukturu

\begin{tabular}{|c|c|c|c|}
\hline Šírka plochy zatížené technickou infrastrukturou & $\check{s}$ & $\mathrm{~m}$ & 0,50 \\
\hline Koeficient míry užitku a omezení podle tabulky č. 1 přílohy č. 22a & $k_{u}$ & & 20,00 \\
\hline $\begin{array}{l}\text { Zvýšení nebo snížení koeficientu podle poznámky za tabulkou č. } 1 \text { př́lohy č. } 22 \mathrm{a} \text { v návaznosti } \\
\text { na druh komunikace a její polohu v obci }\end{array}$ & $\begin{array}{c}a \check{z} \\
30 \%\end{array}$ & $\%$ & 0 \\
\hline Koeficient po ev. úpravě & $k_{u}$ & & 20,00 \\
\hline $\begin{array}{l}\text { Roční užitek oprávněného v Kč za m z věcného břemene pro podzemní technickou infrastrukturu } \\
\text { (§ } 39 \text { b odst. 1) }\end{array}$ & $r u_{z}$ & $\mathrm{Kč} / \mathrm{m}$ & 10,00 \\
\hline \multicolumn{4}{|l|}{ Stanovení ceny věcného břemene $\mathrm{CBz}$} \\
\hline Délka vedení technické infrastruktury & $d$ & $\mathrm{~m}$ & 46,10 \\
\hline Cena věcného břemene $C B z=r u_{z} \times d \times k_{u}$ & $C B_{Z}$ & & 9220,00 \\
\hline
\end{tabular}

k narovnání ocenění u právnických osob, u kterých je věcné břemeno zř́zeno na dobu neurčitou. Podle odstavce 3 se postupuje i v případě věcných břemen zřizovaných s rozvazovací podmínkou.

Odstavec 4 a 5 § 39a řeší případy, kdy nelze prokazatelně určit roční užitek plynoucí z věcného břemene oprávněnému. Pro tyto případy je zachováno stávající ocenění peněžní částkou ve výši 10 tis. Kč. Dále určuje postup oceňování práv zřízených jinak než věcným břemenem obdobných služebnosti nebo reálnému břemenu.

Ustanovení §39b upravuje zjednodušené ocenění, které je určeno pro ocenění věcného břemene pro technickou infrastrukturu ${ }^{2)}$

2) Technickou infrastrukturou se rozumí technická infrastruktura ve smyslu příslušného ustanovení a definice podle stavebního zák'ona č. 183/2006 Sb., § 2: (1) V tomto zákoně se rozumí ... k) veřejnou infrastrukturou na dobu neurčitou pro podzemní vedení umístěné do silničního pozemku nebo do pomocného silničního pozemku (silniční pozemek, včetně pomocného silničního pozemku, je definován v ustanovení § 11 zákona č. 13/1997 Sb., dále i podle § 12, 14 a 15), s výjimkou časově neomezených reálných břemen a vykupitelných služebností, které se oceňují podle $\S 16$ b odst. 4 zákona č. 151/1997 Sb., v aktuálním znění. Členění technické infrastruktury je

pozemky, stavby, zařízení, a to ... 2. technická infrastruktura, kterou jsou vedení a stavby a s nimi provozně související zařízení technického vybavení, například vodovody, vodojemy, kanalizace, čistírny odpadních vod, stavby ke snižování ohrožení území živelními nebo jinými pohromami, stavby a zařízení pro nakládání s odpady, trafostanice, energetické vedení, komunikační vedení veřejné komunikační sítě a elektronické komunikační zařízení veřejné komunikační sítě, produktovody a zásobníky plynu. 
uvedeno například v $§ 2$ odst. 1 písm. k) bod 2 zákona č. 183/2006 Sb., § 1 zákona č. 416/2009 Sb., § 24 odst. 4, § 25 odst. 4, § 57 odst. $2, \S 58$ odst. $2, \S 59$ odst. $2, \S 60$ odst. $2, \S 76$ odst. 7 zákona č. 458/2000 Sb., § 104 zákona č. 127/2005 Sb. Využivání silničních pozemků pro umístění vedení inženýrských sítí je podle odst. 6 , písm. d) ustanovení § 25 zákona č. 13/1997 Sb., o pozemních komunikacích, ve znění pozdějších předpisů], zvláštním uživáním dálnice, silnice a místní komunikace. Vlastníkem dálnic a silnic I. třídy je stát, vlastníkem silnic II. a III. třídy je kraj, vlastníkem místních komunikací je obec, na jejímž území se místní komunikace nacházejí. Pouze u některých účelových komunikací je vlastníkem právnická nebo fyzická osoba (dle ustanovení § 9 uvedeného zákona). Stavby dálnice, silnice a místní komunikace nejsou součástí těchto pozemků. Stavby technické infrastruktury (zejména inženýrských sítí, sítí energetické infrastruktury a infrastruktury elektronických komunikací) jsou ve většině případů zřizovány ve veřejném zájmu (např́íklad zákonem č. 458/2000 Sb., energetický zákon, zákonem č. 125/2005 Sb., o elektronických komunikacích nebo zákonem č. 274/2001 Sb., o vodovodech a kanalizacích). Jedná se tudíž o specifická věcná břemena, proto je pro ně optimální samostatná úprava jejich oceňování.

Z uvedených důvodů Ministerstvo financí považovalo za potřebné určit jednoduchý a jasný postup pro ocenění těchto věcných břemen. $\mathrm{K}$ tomu by mělo přispět uvedené zjednodušené oceňování, které vychází ze stávající praxe při sjednávání ceny věcných břemen mezi obcí a vlastníky předmětných sítí. Ze stávajících vyhlášek obcí, kterými jsou určovány jednorázové úhrady za zřízení věcných břemen na pozemku komunikace pro umístění podzemního vedení je zřejmé, že tyto úhrady mohou vycházet nejen ze zatížené plochy pozemku věcným břemenem, ale rovněž z délky vedení inženýrské sítě. Roční užitek vychází ze základní ceny stavebních pozemků v obci, tím je zajištěna objektivnost určené ceny služebnosti v návaznosti na velikost a význam obce. V současné době není výše požadovaných úhrad některými obcemi objektivní, úhrady jsou i několikanásobně vyšší než je cena stavebního pozemku v obci. Obecní vyhlášky neobsahují jednotný způsob určení těchto úhrad, proto bylo potřebné určování cen zprůhlednit a sjednotit. Roční užitek se určuje vynásobením základní ceny stavebního pozemku koeficientem 0,015. Tento koeficient zahrnuje určení simulovaného nájmu ve výši podílu $5 \%$ z ceny stavebního pozemku a statistického vyhodnocení podílů základních cen stavebního pozemku a dosahovaných průměrných zjištěných cen pozemků pod běžně se vyskytujícími komunikacemi v obci. Umístěním vedení na silničním pozemku nebo pomocném silničním pozemku se pro účely této vyhlášky rozumí umístění vedení vložením do komunikace, krajnice, chodníku, pomocného silničního pozemku a dále překop komunikace (viz tabulka č. 1 př́lohy č. 22a $\mathrm{k}$ této vyhlášce).
K ustanovení § 39c lze uvést, že věcné právo váznoucí na věci je právní závadou, jen pokud není pro nemovitou věc z hlediska ocenění př́nosem. Za závadu se z hlediska oceňování (dle ustanovení §16c zákona o oceňování majetku) nepovažuje právo, které vlastnické, užívací nebo požívací právo k nemovité věci podstatně neomezuje a nemá tak významný vliv na výši její ceny, zejména zástavní právo, zadržovací právo, nájem, pacht nebo právo stavby. Za závadu se naopak považují i ochranná pásma, avšak pouze v prrípadě, že splňují výše uvedenou podmínku zákona. Každá závada se posuzuje samostatně s ohledem na délku jejího trvání a její podíl na omezení vlastníka nemovité věci v jejím užívání. Při určování výše ceny závady se postupuje analogicky jako při určování ceny věcného břemene. V odstavci 3 ostatní př́pady zahrnují např́iklad právnické osoby, svěřenské fondy, aj. Platí, že hodnota nemovité věci po odpočtu souhrnu závad musí činit minimálně $20 \%$ určené ceny nemovité věci.

Za př́lohu č. 22 je pak vložena nová příloha č. 22a, která má následující tabulky:

1. Koeficienty míry užitku a omezení vlastníka nemovité věci pro zjednodušené ocenění věcných břemen technické infrastruktury. $\mathrm{V}$ tabulce č. 1 jsou uvedeny hodnoty koeficientu míry užitku $k_{u}$ pro zjednodušené ocenění věcného břemene pro technickou infrastrukturu, a to v závislosti na umístění vedení v silničním pozemku nebo pomocném silničním pozemku, které zohledňují podíl oprávněného $\mathrm{z}$ věcného břemene na ročním užitku plynoucím z nemovité věci jejímu vlastníkovi.

2. Tabulka č. 2 př́lohy č. 22 a obsahuje hodnoty koeficientu míry užitku a míry omezení vlastníka nemovité věci pro věcná břemena pro technickou infrastrukturu, členěnou podle druhu technické infrastruktury, v závislosti na druhu pozemku, na němž je vedení umístěno. Hodnoty byly navrženy na základě provedené analýzy dat dostupných Ministerstvu financí ČR, ve veřejných rejstřících a s prrihlédnutím $\mathrm{k}$ datům od měst a obcí.

3. Tabulka č. 3 přílohy č. 22 a obsahuje průměrný počet let dalšího trvání věcného břemene zřízeného na dobu života $\mathrm{v}$ závislosti na věku oprávněného $\mathrm{k}$ datu ocenění (viz zde tab. 6, obr. 10).

Jak plyne z tab. 6, tvůrci novely opustili nelogické ustanovení původního znění §16b zákona, odst. 4 („,Patři-li právo určité osobě na dobu jejího života, oceňuje se desetinásobkem ročního užitku“) a přiklonili se k tomu, že by oprávněný měl mít v každém věku prostředky, odpovídající zřízení obdobného věcného břemene po statisticky pravděpodobnou zbývající dobu života, jak plyne také z obr. 10.

\section{Trvalé porosty}

U trvalých porostů byl v jejich seznamu v $§ 14$ (Členění trvalých porostů) zákona o oceňování majetku k lesním porostům, ovocným dřevinám, vinné a chmelové révě přidán pojem rychle rostoucí

Tab. 6 Věk oprávnèného a prüměrný počet let dalšiho trvání věcného břemene.

Tab. 6 Age of the beneficiary and average number of years of further encumbrance.

\begin{tabular}{cc|cc}
\hline Věk oprávněného z VB & Průměrný počet let dalšího trvání VB & Věk oprávněného $\mathbf{z}$ VB & Průměrný počet let dalšího trvání VB \\
\hline Do 16 včetně & 71 & $57-60$ & 22 \\
$17-29$ & 56 & $61-69$ & 16 \\
$30-40$ & 45 & $70-78$ & 11 \\
$41-49$ & 35 & $79-89$ & 6 \\
$50-56$ & 28 & 90 a více & 2 \\
\hline
\end{tabular}




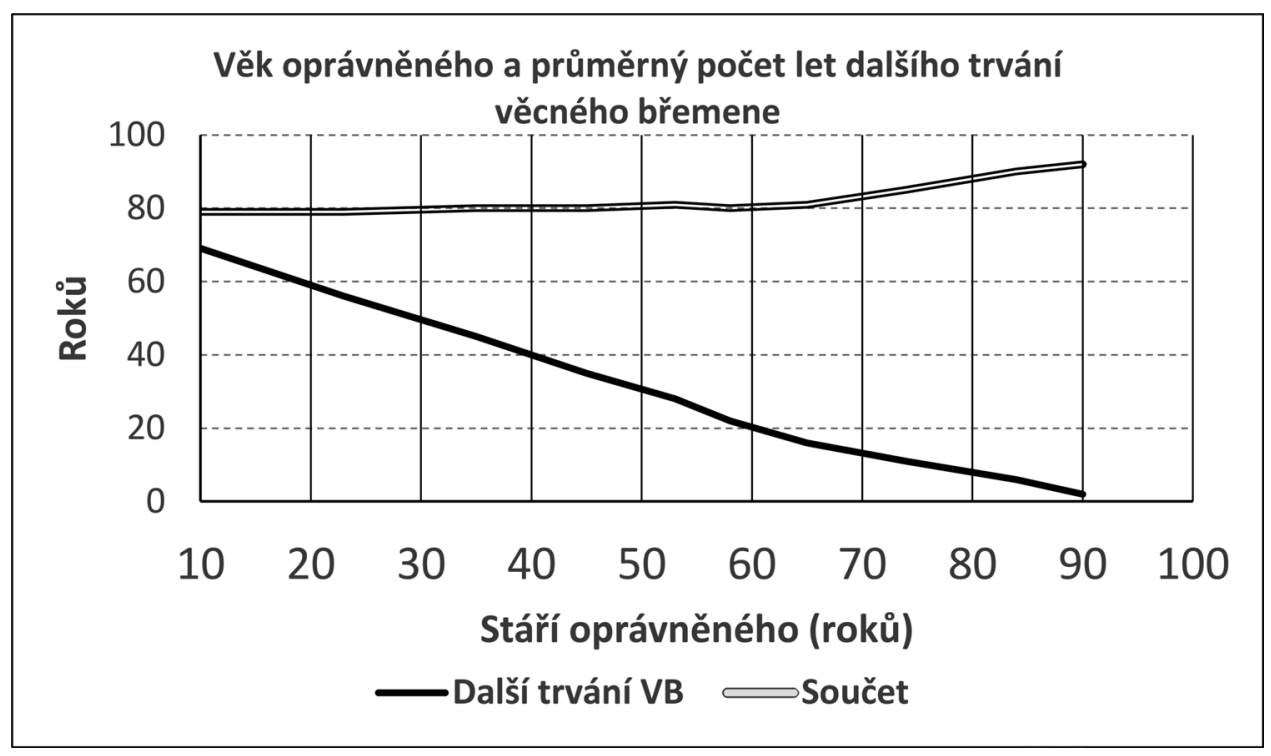

Obr. 10 Věk oprávněného, prưměrný počet let dalšiho trváni věcného břemene a předpokládaná délka života.

Fig. 10 Age of the beneficiary, average number of years of further encumbrance and life expectancy.

dřeviny. Metodika ocenění rychle rostoucích dřevin je uvedena v nově vloženém ustanovení $§ 46$ odst. 2 :

(2) Základní cena a druhy rychle rostoucích dřevin pěstovaných ve výmladkových plantážich na zemédèlské půdě jsou uvedeny $v$ prílohách č. 43 a 42 k této vyhlášce v Kč za $\mathrm{m}^{2}$. Základní cena se vynásobi korekčními faktory porostů a pozemků podle přilohy č. 44 k této vyhlášce a výměrou výmladkové plantáže $v m^{2}$.

Nová př́loha č. 42 obsahuje v tabulce č. 1 produkční druhy (včetně jejich kř́ženců) rychle rostoucích dřevin a v tabulce č. 2 neprodukční (multifunkční) druhy rychle rostoucích dřevin. V tabulkách jsou uvedeny jejich mezinárodní (vědecké) a české názvy.

$\mathrm{V}$ př́loze č. $43 \mathrm{v}$ tabulce jsou uvedeny základní ceny $\mathrm{v} \mathrm{Kč} / \mathrm{m}^{2}$ výmladkových plantáží rychle rostoucích dřevin na zemědělské půdě v členění podle stárí pařezů a kmenů. Ke stanovení ceny výmladkových plantáží rychle rostoucích dřevin byla použita průměrná a v současnosti obvyklá cena štěpky pro energetické př́padně materiálové využití (1 000 Kč/t (sur.) vlhkost 45-55\%; VUKOZ, TZB - info, 2019-2020). Jedná se o cenu porostu na poli se započtením nákladů na založení, ale bez odečtení nákladů sklizně a prodeje. Pro palivové dřevo byla použita cena $2500 \mathrm{Kč} / \mathrm{t}$ (sur.) vlhkost 35-55\%; VUKOZ, TZB-info, 2019 - 2020.

V př́loze č. 44 jsou zařazeny tabulky č. 1 až 5 .

- Tabulka č. 1 obsahuje typy porostu výmladkových plantáži rychle rostoucích dřevin a korekční faktor jejich ceny podle intenzity pěstování, podle účelu produktu a podle druhu pěstovaných dřevin. Nejvyšší korekční faktor mají produkční odrůdy určené na palivové dřevo a nejnižší korekční faktor mají multifunkční a extenzivně pěstované odrůdy určené na štěpku.

- Tabulka č. 2 zahrnuje typy pozemků a jejich korekční faktory podle vhodnosti pro pěstování výmladkových plantáží rychle rostoucích dřevin. Pozemky jsou členěny na optimální, vhodné a nevhodné pro pěstování výmladkových plantáži rychle rostoucích dřevin. Výsledky výzkumu i praxe pěstování výmladkových plantáží rychle rostoucích dřevin od roku 1995 v ČR ukazují, že nejdůležitějším předpokladem pro dosažení dobrých výnosů je volba vhodného stanoviště, které je dáno kombinací půdních a klimatických podmínek. Zejména se jedná o dostupnost vody (půdní a srážkové), fyzikální vlastnosti půdy a další limitující faktory zejména klimatické, které jsou zjistitelné z BPEJ - bonitované půdně ekologické jednotky každého zemědělského pozemku, respektive z prvních tří čísel BPEJ = HPKJ (Hlavní půdně klimatické jednotky).

- Tabulka č. 3 obsahuje hlavní půdně klimatické jednotky (první tři čísla bonitovaných půdně ekologických jednotek) pozemků optimálních pro výmladkové plantáže rychle rostoucích dřevin.

- Tabulka č. 4 zahrnuje hlavní půdně klimatické jednotky (první tři čísla bonitovaných půdně ekologických jednotek) pozemků vhodných pro výmladkové plantáže rychle rostoucích dřevin.

- Tabulka č. 5 obsahuje hlavní půdně klimatické jednotky (první tři čísla bonitovaných půdně ekologických jednotek) pozemků nevhodných pro výmladkové plantáže rychle rostoucích dřevin.

Příklad ocenění RRD podle výše uvedeného je uveden zde $\mathrm{v}$ tab. 7 . V případě potřeby je oceňování porostů rychle rostoucích dřevin možno provést polním šetřením a metodou nedestruktivního odhadu zásoby biomasy $\mathrm{v}$ hmotnostních nebo objemových jednotkách.

\section{Společná, závěrečná a zrušovací ustanovení}

Nově je definován $\S 49$ (původně o snižování ceny nemovité věci o cenu věcného břemene, nyní o cenu závady, hranice $80 \%$ zůstala):

(1) Cena nemovité věci se sniží o cenu závady, kterou je nemovitá věc zatižena, určenou podle $\$ 16 c$ zákona o oceňováni majetku a 39 c.

(2) Cena nemovité věci může být z dưvodu závad, jimiž je zatižena, snižena nejvýše o $80 \%$ určené ceny nemovité věci. 
Tab. 7 Př́klad výpočtu ceny plantáže rychle rostoucich dřevin podle § 46 odst. 2 vyhlášky č. 441/2013 Sb. ve znění vyhlášky č. $488 / 2020$ Sb. Tab. 7 Example of calculating the price of a plantation of fast-growing woody plants according to $\$ 46$ paragraph 2 of Decree No. $441 / 2013$ Coll. as amended by Decree No. 488/2020 Coll.

\begin{tabular}{|c|c|c|}
\hline 1 & Obec (resp. i část obce) & $\mathrm{Xxxxxx}$ \\
\hline 2 & Okres & $\mathrm{Xxxxxx}$ \\
\hline 3 & Kraj & $\mathrm{Mmmm}$ \\
\hline 4 & Katastrální území - název & Kkkkkkk \\
\hline 5 & Katastrální území - číslo & 0 \\
\hline 6 & List vlastnictví č. & Xxxxxx \\
\hline 7 & Parcela číslo & $780 / 10$ \\
\hline 8 & Druh pozemku dle KN & zahrada \\
\hline 9 & Druh pozemku dle skutečnosti & plantáž RRD \\
\hline 10 & Výměra $\left[m^{2}\right]$ & 10000 \\
\hline 11 & Bonitovaná půdně ekologická jednotka BPEJ & 51510 \\
\hline \multirow[t]{2}{*}{12} & Druh RRD dle př́lohy č. 42 & Vrba jíva - produkční \\
\hline & ZC z př́lohy č. 43: & ------------ \\
\hline 13 & Věk plantáže (převažující stáří pařezů) [roků] & 20 \\
\hline 14 & Fáze & produkční (7-21 roků) \\
\hline 15 & Rok stáří kmene (v rámci aktuálního obmýtí) [roků] & 3 \\
\hline \multirow[t]{3}{*}{16} & Základní cena $Z C\left[\mathrm{Kč} / \mathrm{m}^{2}\right]$ & 8,50 \\
\hline & Koeficienty z př́lohy č. 44 : & ------------ \\
\hline & Tabulka 1 př́lohy č. 44: & ------------- \\
\hline$\overline{17}$ & Typ porostu podle intenzity pěstování & produkční \\
\hline 18 & Typ porostu podle hlavního produktu & palivové dřevo \\
\hline 19 & Druhy pěstovaných dřevin (RRD) & produkční odrůdy vrb \\
\hline 20 & Hustota porostu (tis. ks/ha) & 2,5 \\
\hline 21 & Řádek v tab. 1 př́lohy č. 44 & 2 \\
\hline \multirow[t]{2}{*}{22} & Korekčni faktor typu porostu $\left(K F_{\tau}\right)$ & 1,2 \\
\hline & Tabulky 3-5 př́lohy č. 44: & ------------ \\
\hline 23 & BPEJ & 51510 \\
\hline 24 & Hlavní půdně-klimatická jednotka (HPEJ = první 3 čísla BPEJ) & 515 \\
\hline \multirow[t]{2}{*}{25} & HPEJ zařazeno podle vhodnosti pro výmladkové plantáže do tabulky č. & 3 \\
\hline & Tabulka č. 2 přílohy č. 44: & ------------ \\
\hline 26 & Pozemky podle vhodnosti (bonity) pro pěstování & optimální \\
\hline 27 & Korekční faktor typu pozemku $\left(K F_{P}\right)$ & 1,55 \\
\hline 28 & Cena porostu plantáže RRD [Kč] [ $=(10) *(16) *(22) *(27)]$ & 158100,00 \\
\hline
\end{tabular}

Nové znění přesněji (spravedlivěji) vystihuje míru znehodnocení nemovité věci závadou, kterou je nemovitá věc skutečně zatížena. Konkrétně se nově od ceny nemovité věci neodečítá celá cena věcného břemene, ale cena souhrnu závad určená podle $\S 16 \mathrm{c}$ zákona o oceňování majetku a §39c oceňovací vyhlášky, nejvýše však $80 \%$ určené ceny nemovité věci.

\section{LITERATURA}

[1] Zákon č. 151/1997 Sb., o oceňování majetku a o změně některých zákonů (zákon o oceňování majetku), ve znění pozdějších předpisů.
[2] Zákon č. 237/2020 Sb., kterým se mění zákon č. 151/1997 Sb., o oceňování majetku a o změně některých zákonů (zákon o oceňování majetku), ve znění pozdějších předpisů, a další související zákony.

[3] Poslanecká sněmovna PČR - Sněmovní tisk č. 501 - Návrh k zákonu č. 237/2020 Sb. Dostupné na https://www.psp.cz/sqw/ text/tiskt.sqw? $O=8 \& C T=501 \& C T 1=0$.

[4] Vyhláška č. 441/2013 Sb., k provedení zákona o oceňování majetku (oceňovací vyhláška), ve znění pozdějších předpisů.

[5] Vyhláška č. 488/2020 Sb., kterou se mění vyhláška č. 441/2013 Sb., k provedení zákona o oceňování majetku (oceňovací vyhláška), ve znění pozdějších předpisů.

[6] Ministerstvo financí - Odůvodnění novely pro LRV - 2020.

[7] BRADÁČ, A., POLÁK, P.: Úřední oceňování majetku 2021. 1. vydání. Brno: Akademické nakladatelství CERM ${ }^{\circledR}$ Brno, s.r.o., 2021. 336 s. ISBN 978-80-7623-051-4.

\section{Správná citace:}

BRADÁČ, A., POLÁK, P. Změny předpisů pro oceňování věcí nemovitých od 1. ledna 2021. Soudní inženýrství, 2020, 31(4), 49-66. DOI: http://dx.doi.org./10.13164/SI.2020.4.49. ISSN 1211-443X. 